\title{
Bank market power and firm performance
}

\author{
Manthos D. Delis \\ Finance Group and Centre for Banking, Money, and Institutions, Surrey Business School, \\ University of Surrey, Guildford, GU2 7XH, UK \\ Email: m.delis@surrey.ac.uk
}

Sotirios Kokas

Essex Business School, University of Essex, Wivenhoe Park, Colchester, CO4 3SQ

Email: skokas@essex.ac.uk

\author{
Steven Ongena * \\ Department of Banking and Finance, University of Zurich, CH-8032, Zurich \\ Email: steven.ongena@bf.uzh.ch
}

* Corresponding author. We are indebted to Franklin Allen (editor), and one anonymous referee for invaluable comments. We are also grateful to Douglas Gale, Mike Tsionas, and participants of the " $10^{\text {th }}$ Seminar on Risk, Financial Stability and Banking", the " $14^{\text {th }}$ Conference on Research on Economic Theory \& Econometrics (CRETE)" and of Seminars at the University of Surrey, the Athens University of Economics and Business, and the University of Malaga for valuable comments. 


\title{
Bank market power and firm performance
}

\begin{abstract}
Does market power of banks affect firm performance? To answer this question we examine 25,236 syndicated loan facilities granted between 2000 and 2010 by 296 banks to 9,029 US non-financial firms. Accounting for both observed and unobserved bank and firm heterogeneity, we find that firms that were recently poorly performing obtain loans from banks with more market power. However, in the year after loan origination market power positively affects firm performance, but only if it is not too high. Our estimates thus suggest that bank market power can facilitate access to credit by poorly-performing firms, yet at the same time also boosts the performance of the firms that obtain credit.
\end{abstract}

JEL classification: G21; G32; L13

Keywords: Bank market power; Lerner index; Firm performance; Syndicated loans 


\section{Introduction}

What is the effect of bank market power on the performance of the borrowing firms? Answering this question enables us to assess the welfare implications of the efficient functioning of credit markets and the intermediary role banks play in the economy. Vis-à-vis the situation with perfect competition, market power introduces a deadweight loss, which in the loan market results in higher intermediation margins and lower productive efficiency for the borrowing firms.

For the banking sector, however, this market description has to be qualified. A bynow seminal theoretical and empirical literature argues that intense competition between banks, and the resultant close-or-equal-to zero profits in the sector, may increase the likelihood of bank failures and financial instability (e.g., Keeley, 1990). In addition, and equally importantly, a related theoretical literature (e.g., Petersen and Rajan; 1995; Caminal and Matutes, 1997, 2002; Boot and Thakor, 2000) argues that some degree of bank market power may be needed for strong and inter-temporally efficient bank-firm relationships to form. Such relationships may improve access to credit, leading to for example more innovation in healthier product markets, vertical and horizontal firm growth, and - at least in the medium term - higher profitability. Yet, as far as we are aware, little or no empirical work has directly tested the proposition that some bank market power is required to improve firm performance.

In this paper, we empirically analyze the correspondence between bank market power and firm performance, both before and after loan origination. For theoretical guidance we mainly rely on the contributions by Petersen and Rajan (1995), Caminal and Matutes (1997, 2002), and Boot and Thakor (2000). These studies suggest that in order to extract maximum rent, banks with market power are incentivized to lend to firms that are currently relatively poorly-performing but that may well have good future investment opportunities. If banks 
with market power also have a superior screening ability to spot these good investment ideas, funding these projects will be easier for them than for their competitors. Combined with the fact that banks with market power have better screening (Chan, Greenbaum and Thakor, 1986) and monitoring capacity or exhibit greater monitoring effort (Matutes and Caminal, 2002), the credit provision can improve the performance of the borrowing firms. The main reasons for this positive outcome is the availability of credit to fund a promising investment opportunity and the screening and monitoring advantages of banks with market power that safeguard the borrowing firm against suboptimal project selection and loan default.

In view of these theoretical considerations, we focus on two testable hypotheses. First, banks with more market power engage or are engaged by poorly-performing firms (notice that prior to loan origination firm performance should be observable by banks). Above theoretical frameworks indeed imply that engagement may come from both sides (i.e., banks with firms or vice versa). To test this first associative hypothesis we formulate an empirical model that relates past performance of firms to the current market power of banks (i.e., the matching between firms and banks before the loan origination). Second, bank market power positively impacts the performance of the borrowing firms, because of the mere provision of credit and/or because banks with market power screen and monitor better thereby fostering superior investment ideas and outcomes. We test this second causal hypothesis by analyzing the effect of current bank market power on future firm performance.

A notable feature in testing our first hypothesis is that we simply observe the matching process, taking the syndicate structure as given. That is, we do not provide any information about whether the borrowing firms initiate the relationship with banks with market power to gain access to credit or whether the lead banks choose the borrowing firms with inferior performance but profitable projects. To analyze the initiation of the bank-firm relationship we need data that is not generally available (e.g., data on loan applications, bank 
networks, etc.). Similarly, the empirical tests of the second hypothesis use information only on established relationships (and syndicate structures) and are agnostic about how the results would change for originated loans that were initiated by firms compared to those initiated by banks.

We use data from the US syndicated loan market over the period 2000-2010. This market includes large corporate loans granted by a syndicate of large banks to a single firm. Subsequently, we obtain information on characteristics of banks and firms from a number of other databases. This procedure yields a unique multi-level sample that contains many instances of multiple loans made by a single syndicate lead bank and/or obtained by a particular borrowing firm. We estimate the market power of banks at the bank-year level using the Lerner index (1934), which measures deviations of prices from marginal cost (Beck, De Jonghe, and Schepens, 2013; Delis, Kokas, and Ongena, 2015), and capture firm performance with several variables, including the return on assets (ROA), return on income (ROI) and Tobin's q.

Estimating a bank market power equation (i.e., the first hypothesis) or a firm performance equation (i.e., the second hypothesis) is inevitably subject to severe omitted variables` concerns. The multi-level structure of our sample, i.e., multiple loans provided by the same bank and multiple loans obtained by the same firm, is in this respect important because it allows us to include comprehensive sets of both bank and firm fixed effects when estimating our empirical models.

The first set of estimates we obtain documents that the firms that are relatively poorlyperforming match with banks that have more market power. Specifically, we show that a firm with an ROA that is one standard deviation higher than average (in the year prior to loan origination) matches with a bank with a Lerner index that is 44 percent lower (in the year of loan origination). The second set of estimates suggests a positive impact of bank market 
power on firm profitability. In particular, an increase in the Lerner index of the bank by one standard deviation (in the year of loan origination) increases the ROA of the borrowing firm (in the year after loan origination) by 1.2 percentage points, a substantial increase as the average ROA in our sample is equal to 1.5 percent.

Our results are robust to the use of alternative measures, e.g., Tobin's q as a measure of firm performance, and for a variety of sub-samples and model specifications. We focus for example on the set of loans with syndicates that are recurring through time and then (in addition to many other controls) load in comprehensive sets of bank, firm and eventually also bank syndicate - firm fixed effects. Most of the remaining time series variation will then originate with the Lerner index, constituting a powerful test of the direct impact of the Lerner index on firm performance.

Alternatively, we employ as an instrumental variable the formal regulatory enforcement actions enacted on banks for violations of rules on the internal control and audit systems. We expect these actions to be positively correlated with bank market power, because banks with more market power may be less transparent with respect to their internal control and audit systems. At the same time, these actions should in principle not have any direct impact on firm performance (also given the many bank-level control variables and the set of bank fixed effects that are also included).

Finally, we show that specific elements characterizing the monitoring incentives of banks (i.e., the capacity to use soft information to monitor the loans, the significance of the loan to the firm, the number of syndicate lenders, and the loan amount weighted by the shares of the syndicate members) enforce the positive impact bank market power has on future firm performance. In this respect our results are consistent with Besanko and Kanatas (1993), who show that bank loans are "special" because they combine lending with the provision of 
monitoring services that increase entrepreneur effort and thereby improve the project's success probability.

In sum, these findings are overall consistent with theory providing a monitoring-based explanation of the positive impact of current bank market power on future firm performance (Caminal and Matutes, 1997, 2002; Boot and Thakor, 2000). However, we also find that for a limited number of very large values of the Lerner index (that would suggest nearmonopolistic behavior of banks), the effect of market power on firm performance turns negative. This implies that too much market power is eventually harmful for the borrowing firms. In fact, this finding is consistent with implications from the theoretical framework of Boyd and De Nicolo (2005), who show that as banks charge higher loan rates due to lower competition, the borrowers optimally increase their own risk of failure. Thus, our empirical results explain these two competing theories dealing with the real outcomes of bank-firm relationships according to the degree of competition in the banking sector.

The remainder of our paper is structured as follows. Section 2 sets the context of our study and formulates the two testable hypotheses. Section 3 describes the empirical model and the data used in the empirical analysis. Section 4 discusses the empirical identification procedure and the estimation results. Section 5 summarizes the results and provides policy implications.

\section{Testable hypotheses}

The traditional view on competition in the banking sector is that - as in any other sector - it enhances the efficiency and the quality of production of banking products and the welfare of borrowers. These can be achieved through the decline in interest rate margins, increased access to finance and better investment opportunities for firms and households (Besanko and Thakor, 1992; Petersen and Rajan, 1995). However, the welfare implications of competition 
in the banking industry are not as straightforward as in other industries. Keeley (1990) was perhaps the first to point out that more intense competition in banking (in terms of low pricecost margins) leads to a more risky banking sector through the increased incentives of competitive, and thus less profitable, banks to take on higher risks (margin effect). The empirical tests in this literature, e.g., Jimenez, Lopez, and Saurina (2013), focus on the relation between bank market power and risk, almost entirely disregarding the role and the performance outcomes of the borrowing firms. ${ }^{1}$ However, the theoretical literature is not only about banks; it also considers the bank-firm relationships and their effect on the real economy.

The bank-firm relationship has two components: there is (i) the matching process between banks and firms prior to the loan origination; and there is (ii) the performance of the borrowing firms after the loan origination. Considering the former, Petersen and Rajan (1995) suggest that banks in a competitive market are constrained to break even on period-by-period basis and are unlikely to provide credit to distressed or young firms with relatively low performance measures, even though the investment opportunities of these firms are profitable. In contrast, banks with monopoly power can better extract future rents from profitable projects of relatively poorly-performing firms, because they can afford to provide risky credit to these firms.

Similarly, Boot and Thakor (2000) theoretically show that as bank market competition increases (decreases) banks make more (less) relationship loans, but each loan has more (less) added value for borrowers. In this model banks with more market power lend to borrowers with low a priori performance but with profitable investment opportunities. This is the case because banks optimally prefer to capture most of the incremental benefit of a relationship loan.

\footnotetext{
${ }^{1}$ An exception is Cetorelli (2004), who explores whether bank concentration affects the structure of nonfinancial industries, using a panel of manufacturing industries in 29 OECD countries. The evidence suggests that lower concentration in the banking industry leads to a lower average firm size.
} 
A further issue worth mentioning is that an empirical literature suggests that banks with market power possess a superior ability to screen the profitable investment ideas (e.g., Gehrig, 1998). Also, firms perceived as highly risky might be more easily rejected by capital markets and will be forced to accept the tighter terms of private lenders. To the extent that these tighter terms also include borrowing from banks with higher price-cost margins, these firms would be matched with high market-power banks. In sum, these influential theoretical papers allow us to formulate the following empirically testable hypothesis:

H1: Low-profitability firms will tend to be matched with banks with high market power.

An analysis of the matching process for banks and firms has its own merits, but perhaps the most important issue for real economic outcomes concerns the future performance of the firms that borrow from banks with more market power. Boyd and De Nicolo (2005) reconsider the competition-fragility nexus in Keeley (1990) by focusing on the role played by firms. They show that as competition declines, banks charge higher loan rates, which imply higher bankruptcy risk for borrowers. Then, within a moral hazard framework, the borrowing firms optimally increase their own risk of failure (risk-shifting effect).

The most relevant theoretical models for our purposes are these of Boot and Thakor (2000) and Caminal and Matutes $(1997,2002)$. One of the findings of the former study is that lenders can improve the future borrowers' performance (project payoff) through intense monitoring of the loan after its origination and that this monitoring can generate higher borrower surplus to be shared between the lender and the borrower. Caminal and Matutes (1997) explicitly study the welfare implications of market power in banking and suggest two opposing effects being at work. On the one hand, higher market power worsens the terms of credit and reduces investment, but on the other hand higher market power induces banks to 
exert higher monitoring effort and reduces the frequency of credit rationing. Whenever the second effect dominates, some degree of market power is beneficial for economic welfare. Similarly, Caminal and Matutes (2002) show that banks' incentives to exert monitoring effort increase with market power, by allowing banks to commit to monitoring in order to reduce agency problems.

Banks with some market power in lending can enhance the borrower's performance in at least five ways. Most of these ways stem from the idea that banks with some market power are able to finance projects with a positive expected payoff that competitive banks cannot (Petersen and Rajan, 1995). First, the mere funding by a bank with market power of an investment idea with a positive expected payoff will generate increased profitability for the borrowing firm. This implies that the bank with market power has both the financial capacity to provide the required credit to a good investment idea and that banks with market power have superior ability to screen the good investment ideas (Chan et al., 1986). Second, a bank with market power could provide additional financing to a liquidity-constrained firm even after the initial loan origination. This financing may come via an extra loan facility (commitment), with an accompanying enhancement in the borrower's payoff. Third, a bank with market power can more effectively increase the debt payoff restructuring of a financially distressed borrower by performance pricing. Fourth, this bank may hold other loans in the industry and know more about this industry compared to its borrowers, thus being able to provide valuable advice. Fifth, assuming that banks with market power have a superior monitoring capacity (which they developed through a learning-by-doing process), the nexus between the market power of banks at the time of loan origination and the future performance of firms should be positive. ${ }^{2}$

\footnotetext{
${ }^{2}$ Caminal and Matutes (2002) show that incentives to monitor are enhanced by market power.
} 
A number of empirical papers analyze the bank-firm relationship and indirectly offer additional potential explanations for a link between bank market power and future firm performance. De Haas and Van Horen (2013) for example study the syndicated loan market and suggest that local lending experience also gives banks more market power vis-a-vis their borrowers (who have even less incentive then to switch to another bank and banks can exploit this by charging a higher interest rate). This is because through repeat lending (lending experience from the same banks that participate in the syndication or lending to the same firm), banks reduce information asymmetries and build up proprietary information about borrowers. Petersen and Rajan (1994) and Dass and Massa (2011) show that a stronger bankfirm relationship may even improve the borrower's corporate governance and therefore increase its value. For instance, relationship lending can lower the interest rates charged by the banks. Moreover, a bank may be interested in preserving the market value of the firm to avoid an increase in the firm's market leverage, or just to preserve the market valuation of the collateral posted by the borrower.

The theoretical considerations discussed above, especially those in Petersen and Rajan (1995) and Boot and Thakor (2000) versus those in Boyd and De Nicolo (2005), also suggest that there may be a non-linear relation between bank market power and firm performance. This type of relation would be similar to the proposition in Caminal and Matutes (1997) on the two opposing forces of bank market power affecting economic welfare analyzed above. Further, Martinez-Miera and Repullo (2010) suggest that the risk-shifting effect identified by Boyd and De Nicolo (2005) dominates in monopolistic markets, whereas the margin effect identified by Keeley (1990) dominates in competitive markets. Even though the model of Martinez-Miera and Repullo concerns bank risk as the outcome variable (and not firm risk or performance), we could theoretically conceive a similar outcome for the bank-firm relationship: Too much bank market power could eventually trigger a situation where firms 
optimally decide to default on their loans due to the oppressing level of market power attached to this loan.

Whether the effect of bank market power on firm performance after loan origination is positive, negative or hump-shaped becomes an empirical question. However, we should note that most of the directly relevant theoretical literature and the indirectly relevant empirical literature point to a positive effect of bank market power on future firm performance. Thus, we formulate our second testable hypothesis as follows:

H2: Bank market power has a positive effect on the performance of the borrowing firms after the origination of the loan.

The two testable hypotheses are interrelated in a dynamic way. Specifically, the relatively poorly-performing firms before the origination of the loan (reference to H1) might improve their performance (reference to H2) if they borrow from banks with market power. Thus, an empirical analysis that validates both $\mathrm{H} 1$ and $\mathrm{H} 2$ will suggest a beneficial effect of market power in banking that has not been explored yet (as far as we know) in the related empirical literature.

It is important at this stage to note two issues. First, the discussion here refers to relatively developed banking and financial systems. If markets are not deep enough and institutions are weak, then the forces highlighted above might not be at work and market power can be damaging to firm performance (see also Delis, 2012). Second, there is a stark difference between the two hypotheses in terms of causality. Hypothesis 1 does not imply a causal relation; it just infers that firms with relatively low profitability will be matched with banks with relatively high market power. In contrast, Hypothesis 2 suggests a positive impact from bank market power on firm performance in the period after loan origination. 


\section{Empirical model and data}

Based on our two hypotheses, we estimate two different empirical models. First, we examine whether banks with high market power are matched with relatively poorly-performing firms. This translates to an empirical model of the form:

Lerner $_{b, t}=\varphi R_{f, t-1}+\delta_{1} F_{f, t-1}+\delta_{2} L_{l t}+\delta_{3} B_{b, t-1}+\varepsilon_{f b t}$.

In equation (1) the market power, labelled "Lerner", of bank $b$ at the time of loan origination $t$, is regressed on the performance $R$ of firm $f$ at $t-1$, a vector of firm characteristics $F$ at $t-1$, a vector of loan characteristics $L$ at $t$, and a vector of banks' characteristics $B$ at $t-1$. The term $\varepsilon$ is a stochastic disturbance term. For identification purposes we also include both bank and firm fixed effects. Their inclusion we discuss further below.

The timing of the variables is in line with the idea that the firms with certain characteristics at time $t$-1 will seek to obtain a loan at time $t$ from a bank (or a number of banks) with a level of market power Lerner at that time $t$. In addition, banks with a specific Lerner at time $t$ will check the available financial statements of the firms from the previous period $t-1$ to decide on the origination of the loan or not (statements from the period $t$ would not be available yet). Our testable hypothesis $\mathrm{H} 1$ implies that $\varphi$ should be negative and statistically significant, indicating that firms with relatively low performance are associated with banks' with more market power.

In turn, $\mathrm{H} 2$ refers to the effect of banks' market power on the performance of firms after the loan agreement. The fielded empirical model is:

Performance $_{f, t+1}=\theta_{0}$ Performance $_{f, t}+\gamma$ Lerner $_{b, t}+\theta_{1} F_{f, t-1}+\theta_{2} L_{l t}+\theta_{3} B_{b, t-1}+u_{f b t}$,

where $\mathrm{u}$ is the stochastic disturbance, and the rest of the variables are as above. H2 implies that $\gamma$ is positive and statistically significant and the timing of the model assumes that the market power of bank at time $t$ has an effect on the performance of firms in the next period. 


\subsection{Data and the syndicated loan market}

We construct a unique database including information on syndicated loans, the involved banks, and the borrowing firms. We focus on US syndicated loan deals for the period 2000$2010 .^{3}$ We draw data from five different data sources and match them to construct our final sample. Our data sources are the Thomson Reuters LPC's DealScan database, the Call reports from the Federal Reserve Board of Governors (FRB), Compustat, the New Generation Research Bankruptcy (NGRB) database, and hand-collected data on enforcement actions that have been enacted by the three main U.S. banking supervisory authorities (FDIC, OCC, and RFB).

We begin with only a brief description of the syndicated loan market, as this market has been extensively analyzed before by a number of studies (e.g., Sufi, 2007). The syndicated loans are credits granted by a group of banks to a single borrower. Loan syndication allows banks to compete with the capital markets in the generation of relatively large transactions that a sole lender would not otherwise be able (or willing) to undertake due to internal and regulatory restrictions. These loans represent a hybrid instrument, combining features of relationship and transactional lending. They allow the sharing of credit risk between various financial institutions without the disclosure and marketing burden that bond issuers face.

In general, the syndication process works as follows. The borrowing firm signs a loan agreement with the lead arranger, who specifies the loan characteristics (collateral, loan amount, covenant, a range for the interest rate, etc.). The members of the syndicate fall into three groups, namely the lead arranger or co-leads, the co-agents, and the participant lenders.

\footnotetext{
${ }^{3}$ We decided to restrict our analysis to this period because of two main reasons. First, we lack data on important variables before 2000. Second, there are important banking regulatory reforms before 2000 (Gramm-LeachBliley Act of 1999 and other earlier ones) and in 2010 (Dodd-Frank Act of 2010) that clearly affect both bank market power and firm performance in non-uniform ways across banks and firms.
} 
The first group consists of senior syndicate members and is led by one or more lenders, typically acting as mandated arrangers, arrangers, lead managers or agents. If two or more lead arrangers are identified, they are then co-leads. Lead arrangers coordinate the documentation process, choose whom to invite to participate in the loan syndicate and may delegate certain tasks to the co-agents. In addition, the lead arranger receives a fee (paid by the borrower) for arranging and managing the syndicated loan.

The co-agents are not in a lead position but they collaborate with the lead arranger in administrative responsibilities, as well as in the screening and monitoring efforts. The lenders with neither lead nor co-agent roles are classified as participant lenders. These lenders can provide comments and suggestions when the syndication occurs prior to closing. However, they are not generally involved in the negotiations or the information sharing between the borrower and the lead arrangers (or the co-agents if applicable). The price and the structure of the loans are determined in a bargaining process that takes place between the lead bank and the potential participants after the non-price characteristics of the loan are set.

A key aspect differentiating a syndicated loan from multiple sole-lender loans is that the members of the syndication reduce their costs by avoiding staff, monitoring, and origination costs. However, this benefit comes at a cost. The loan syndication market could display some unique types of agency problems, stemming both from adverse selection and moral hazard. The adverse selection problem arises when the participant lenders do not have private information about the borrower's quality. The moral hazard problem emerges when lenders decide to sell in the secondary market parts of the loan to a "passive" lender whose incentives to monitor are reduced.

The information for the syndicated loan deals is from DealScan. This database provides detailed information on the loan deal's characteristics (amount, maturity, collateral, borrowing spread, performance pricing, etc.), as well as more limited information for the 
members of the syndicate, the lead bank, the share of each bank in the syndicated (which is important in the construction of our measure of market power discussed below) and the firm that receives the loan. ${ }^{4}$

To obtain information for the financial statements of the banks we match these data with the Call Reports. ${ }^{5}$ Because these reports are available on a quarterly basis, we match the information on the origination date of the loan deal with the relevant quarter. For example, we match all syndicated loans that were originated from April $1^{\text {st }}$ to June $30^{\text {th }}$ with the second quarter of that year of the Call Reports. ${ }^{6}$ In a similar fashion, we obtain information for the financial statements of firms from Compustat, the information being available annually. Further, the New Generation Research Bankruptcy database provides information for the timing of borrower defaults. Subsequently, we assume that an outstanding loan defaults if the borrowing firm also defaults.

Our analysis is conducted at the "loan-facility" level, as opposed to the "loan-deal" level. The difference between the two is that the loan facility refers to each individual portion of a deal, whereas the deal itself comprises potentially multiple loan facilities and covers the full amount of credit granted to the firm on that occasion. A loan-facility analysis is appropriate for the following reason. Loan facilities may have different starting dates, maturity, amount, and loan type. Hence, multiple loan facilities, even when in the same loan deal, cannot be treated as fully dependent observations (e.g., simply adding facilities and ignoring their differences, may therefore introduce a bias in the estimates). However, all

\footnotetext{
${ }^{4}$ Note that some loans in our sample (2,620 observations in total) are amendments to original loan agreements. In the syndicated loan market, unanimity of all syndicate members is required for any change in major terms of the original contract. The DealScan database gathers amendment data and considers amendments that require unanimous consent to be new loans. As a result, such amendments are recorded as independent deals that cannot be distinguished from new issuances. Yet, excluding the amendment loan facilities from our sample does not produce any differences in our results.

${ }_{5}^{5}$ We hand-match Dealscan's lender ID with the commercial bank ID (RSSD9001) from the Call Reports. This process yields a unique identity for each lender. In turn, we link the lenders at their top holding company level (RSSD9348) to avoid losing observations (Cai, Saunders, and Steffen, 2012).

${ }^{6}$ The banks used in our sample are relatively homogeneous in their activities and specialization. Thus, alternative explanations of the findings based on bank specialization (and not based on screening and monitoring of projects) may not be applicable.
} 
results presented below are robust to a loan-deal analysis. In our sample, 80 percent of the loan deals contain only one facility, and the remainder two or more facilities.

The matching process yields a maximum of 25,236 loan facilities (17,952 loan deals), originated by 296 banks and involving 9,029 non-financial firms. However, the number of observations used for the regressions is a bit lower depending on the availability of data for the different variables used. This sample is a so-called multi-level data set, which has observations on banks and firms (lower level) and loan deals (higher level). This is a unique feature that proves particularly helpful for econometric identification purposes. Table 1 formally defines all variables used in the empirical analysis and Table 2 offers summary statistics. We briefly discuss these variables in turn. The bottom panel of Table 1 shows that most of the variation in the Lerner index is between banks as opposed to within banks over time.

[Insert Tables $1 \& 2$ about here]

\subsection{Measures of bank market power}

The measurement of market power of banks has received much attention in the literature. The Lerner index (1934) remains to this day a popular measure of market power, measuring departures from the competitive benchmark of marginal cost pricing. It is defined as:

Lerner $_{b t}=\frac{P_{b t}-M C_{b t}}{P_{b t}}$

where $P$ and $M C$ are the price of bank output at time $t$ and the marginal cost of the production of this output, respectively. The Lerner index ranges between zero and one, with zero corresponding to perfect competition and larger values reflecting more market power (and less competition). The index can also be negative if $P<M C$, which is of course not sustainable in the long run (at least for a market-based financial institution). 
The Lerner index has a number of characteristics that make it an appealing measure of market power. First, the Lerner index is perhaps the only structural indicator of market power that can be estimated at the bank-year level. This is quite important for the purposes of our study, as we examine bank-firm relationships. Second, as Beck, De Jonghe, and Schepens (2013) argue, the Lerner index is a good proxy for current and future profits stemming from pricing power, while it is not constrained by the extent of the market. Moreover, the Lerner index captures both the impact of pricing power on the asset side of the banks' balance sheet and the elements associated with the cost efficiency on their liability side.

Alternative measures of market power include the H-statistic (Panzar and Rosse, 1987) and the profit elasticity (Griffith, Boone, and Harrison, 2005). The H-statistic has been widely used in banking studies, but has two main shortcomings. First, as Bikker, Shaffer, and Spierdijk (2012) point out, the H-statistic maps the various degrees of market power only weakly and thus cannot be viewed as a continuous variable. Second, it is quite difficult to measure and interpret the H-Statistic as a bank-year measure of market power. The profit elasticity (or Boone indicator) has been used in some recent studies but has also received criticism, especially concerning its empirical implementation. For example, Schiersch and Schmidt-Ehmcke (2010) show that the empirical equivalent of the Boone indicator makes critical assumptions relative to firm size and to the definition of the market. Further, it is also difficult to estimate the Boone indicator at the bank-year level.

Computation of the Lerner index requires knowledge of the marginal cost. When such information is unavailable (as in most empirical data sets), the marginal cost can be estimated using econometric methods. A popular approach has been to estimate a translog cost function and take its derivative to obtain the marginal cost. Some recent work has shown that it is possible to improve on this methodology with semiparametric or nonparametric methods that allow for more flexibility in the functional form (Delis, Iosifidi, and Tsionas, 2013; Delis, 
Kokas, and Ongena, 2015). As we follow the exact same approach as in Delis, Kokas, and Ongena (2015), we only provide salient details in the online Appendix A. ${ }^{7}$ We also consider the sensitivity of our results using and the translog cost (parametric method) function to estimate marginal cost (e.g., Beck, De Jonghe, and Schepens, 2013).

Notably, the Lerner index is an absolute measure of market power and needs to be weighted with the share of each bank in the syndicated loan. Our database contains full information on loan shares for 24 percent of all loans and for these loans we allocate the exact loan portions to the individual lenders. For the other 76 percent we primarily employ the approach introduced by De Haas and Van Horen (2013); that is we divide the loan equally among the syndicate members. Section 4.2 presents robustness tests that show that our results also hold when we allocate the shares for the 76 percent of the sample in other ways (as in De Haas and Van Horen).

\subsection{Measures of firm performance}

Our main measure for firm performance is the return on assets (ROA), which is used by the majority of the corporate finance literature (e.g., Adams and Ferreira, 2009). In our baseline specifications we calculate ROA as the net firm income over total assets. We also use a variant of this traditional definition for ROA, namely the ratio of income before extraordinary items over total assets, henceforth abbreviated as ROI (Dass and Massa, 2011).

Another commonly-used measure of firm performance that we also employ in our analysis is Tobin's q (as in e.g. Adams and Ferreira, 2009; and Dass and Massa, 2011). Tobin's q is a future-oriented and risk-adjusted measure of performance, reflecting the premium that the capital market will pay for a given level of firm assets. Finally, we also use a measure of firm leverage, constructed by the ratio of long-term debt to total assets. The

\footnotetext{
${ }^{7}$ Also, in Table A1 of the same appendix, we report the annual averages and the weighted (by the shares of each bank that participate in the syndicated loan) annual averages of the Lerner index.
} 
higher this ratio, the higher the degree of leverage and consequently the lower the firm`s performance.

\subsection{Control variables}

Consistent with previous studies (e.g., Sufi, 2007; Cai, Saunders and Steffen, 2012), we include several loan-level, bank-level, and firm-level control variables to rule out other possible explanations for our results (we provide formal definitions in Table 1 and summary statistics in Table 2). Loan facilities mainly differ across the amount, maturity, loan scale, interest rates, and loan type (term loan vs. revolver line). Thus, we control for these differences through adding loan-level variables that include the size of the loan (deal amount), the time to maturity (maturity), the deal amount over firm's total assets (loan scale), the all-in-spread-drawn (AISD) as a measure of the pricing of the loan, a dummy that equals to one if the loan is a revolver line credit (revolver), and a series of dummy variables describing a number of loan-quality characteristics. Specifically, we include a dummy variable equal to one when the loan is downgraded and zero otherwise (downgrading) to control for the credit rating of loan's devaluation (Sufi, 2007); a dummy variable equal to one when a borrower defaulted during the life of the loan (default) to control for bankruptcies (Cai, Saunders and Steffen, 2012); the number of financial covenants (financial covenants) to control for unobservable borrower risk factors (Carey and Nini, 2007); a dummy variable equal to one if the loan has collateral (collateral) to control for problems of information asymmetry (Sufi, 2007); and a dummy variable equal to one if a performance pricing option is included in the loan contract (performance pricing) to control for borrower's business prospects (Ross, 2010).

Concerning the bank-level control variables, we use non-performing loans as a measure of ex post bank credit risk; the ratio of interest expenses to total assets (interest 
expenses) to control for the interest coverage and the efficiency of the bank in managing core liabilities; the ratio of tier 1 capital to total loans (tier 1) to control for bank capitalization; the natural logarithm of real total assets (bank size); and the ratio of customer deposits to total assets (deposits) to control for the level of bank deposits supporting total assets.

Finally, at the firm level, we control for firm size, measured by the natural logarithm of total assets; the number of syndicated loans that a firm has received during a year (number of loans) to control for the available information on the borrower especially to guide potential participant banks; a dummy variable that equals to one if the firm has a previous lending relationship with the lead arranger in the last five years (client) as a proxy for the closeness of their relationship; firm efficiency measured by sales to total assets to control for asset turnover; firm age as a proxy for information availability and experience of the firm; and the natural logarithm of sales over turnover (firm sales) to control for future profits' capability.

\section{Empirical identification and estimation results}

\subsection{Empirical identification}

In our empirical analysis, and following the usual practice in studies of the syndicated loan market (e.g., Cai, Saudners and Steffen, 2012; De Haas and Van Horen, 2013), we use the available observations for all the participants in each syndicated loan and not only those for the lead arranger(s). In loan syndication, all members share loan documents (loan agreement, collateral, covenant, etc.) and provide comments, suggestions, and any available information to enhance screening and monitoring ability of the lead bank(s). Each member is a lender to the borrower, with every bank's claim evidenced by a separate note. Song (2004) suggests that banks co-manage deals in order to enhance their services (monitoring and transactions activity) in response to clients' specific needs. Also, the lead arrangers choose to collaborate with those banks that have a similar focus in terms of lending expertise. Moreover, the lead 
arrangers assign more responsibilities to banks that they are already "connected" with, and delegate some monitoring duties accordingly (Cai, Saunders, and Steffen, 2012). However, we do show that our findings are robust to the analysis being conducted for different levels of clustering (bank, loan facility, etc.), for different sub-samples, and only for the lead arrangers.

In equation (1) we are only concerned with the matching of firms and banks and not with the identification of a causal relation running from firm performance to bank market power. Thus, we are interested only in reducing the omitted-variable bias, as this might affect the economic significance of $\varphi$. The omitted-variable bias could arise because there are unobservable reasons behind the choice to lend to a specific firm or borrow from a specific bank. On this front, the structure of our sample, including multiple loans made by each bank for each firm, allows including both bank and firm high dimensional fixed effects. This identification strategy essentially accounts for other unobserved bank and, most importantly, firm-specific characteristics that could inflict a correlation between $\varphi$ and $\varepsilon$. In alternative specifications we also include loan purpose fixed effects. The particular methodology used is thoroughly described in Gormley and Matsa (2014). Khwaja and Mian (2008), and following them Jimenez, Ongena, Peydro, and Saurina $(2012$; 2014) for example, use a similar identification method to avoid the omitted-variable bias.

In contrast, in equation (2) we are interested in identifying a causal relation running from bank market power to firm performance. In this sense, endogeneity can arise both from reverse causality and an omitted-variable bias. We account for reverse causality by lagging all the right-hand side variables except for loan characteristics. This is intuitive both statistically and theoretically. From a statistical viewpoint, explanatory variables in lags can potentially diminish endogeneity issues that emerge due to reverse causality. On the theoretical side, it will probably take some time after the origination of the loan for bank 
market power to have an effect on the performance of the borrowing firms through monitoring for example.

We essentially eliminate the omitted-variable bias using the same strategy with that for the estimation of equation (1), i.e., we use high dimensional fixed effects for firms and banks. Consequently, our identification strategy yields a very large R-squared value. We should perhaps note that the time dimension is not an issue, because the loan deals are unique (not repeated in time). Our sample of loan facilities is essentially a cross-section of loans across banks and firms and we include data for variables according to the timing noted in equations (1) and (2). That is, we do not use a true panel data set for firms and banks, in the sense that loan facilities are not repeated. Thus, the effect of the general conditions affecting bank market power and firm performance is already captured by the loan-level controls and the bank- and firm-related fixed effects. ${ }^{8}$

\subsection{The matching of low-performance firms with high-market power banks}

In Table 3 we report the baseline regression results from the estimation of equation (1). The adjusted R-squared value, ranging from 0.91 to 0.97 , shows that the inclusion of bank and firm fixed effects almost eliminates the omitted-variable bias. The coefficient on lagged ROA in all specifications is negative and statistically significant at the 5 percent level, showing that the firms with relatively low ROA in the year before the loan origination will be matched with banks with high market power. To provide an example of the economic significance of our results for the bank-firm relationship, consider a firm with ROA equal to a one standard deviation lower than our sample's mean. Based on a linearity assumption for the relation

\footnotetext{
${ }^{8}$ Including bank*year and firm*year fixed effects is still feasible, as some banks give out more than one loan within a given year and some firms obtain more than one loan facility within a given year. However, these effects almost completely identify equations (1) and (2) and may not add much to the identification, given that the loan-level controls and the bank and firm fixed effects already incorporate the information defining the bank-firm relationship.
} 
between ROA and the Lerner index, ${ }^{9}$ and according to specification I, a firm with a one standard deviation higher ROA (0.456) will be matched with a bank with a 0.004 points lower Lerner index (calculated from the product $0.009 \times 0.456$ ). This represents around 10 percent of its mean and standard deviation (that equal 0.037 and 0.051 , respectively). The opposite will hold for a firm with a one standard deviation lower ROA. This findings seems to confirm $\mathrm{H} 1$ (or more appropriately, reject its alternative) on the matching between the low profitability firms and banks with high market power.

[Insert Table 3 about here]

In columns II-VI, we examine the sensitivity of our results to several re-specifications of column I. Our findings are qualitatively the same and economically more significant when we carry out our analysis at the loan-deal level (column II). In model III, we conduct an analysis only for lead arranger(s). In this case, the variance of the standard error increases due to the smaller sample, but the coefficient on the $\mathrm{ROA}_{\mathrm{t}-1}$ remains negative and gains in economic significance. In column IV, we exclude loans originated for leveraged buyouts (LBOs) or mergers and acquisitions (M\&As) because these loans can lower the cost of debt by reducing the asymmetric information between the bank and the borrowing firm (Ivashina and Kovner, 2011). ${ }^{10}$ However, the results are almost identical to those of column I.

In column $\mathrm{V}$ we estimate equation (1) only for revolving credit (up until now we control for the loan type, revolver or term loans, by using the revolver dummy variable). Revolver loans, also known as bank lines of credit, loan commitments or credit facilities, are one of the main liquidity instruments for corporations. Our theoretical considerations mostly apply to revolver loans and not to term loans and it is important to exclude the former and examine the robustness of our results. However, our results are again almost identical to those

\footnotetext{
${ }^{9}$ We examine possible non-linear effects by adding the squared term of $R O A$ among the regressors, but we find no such effects.

${ }^{10}$ The cost of financing might be lower because the bank has acquired private information about the borrowing firm from prior transactions, which might, for example, enhance its confidence in the firm's due diligence process.
} 
in column I. In column VI, we drop loans in which the lead arranger is one of the largest three U.S. banks, namely J.P. Morgan Chase, Bank of America, and Citigroup. This analysis allows us to examine whether results are driven solely from the efficiency of the very large banks to originate large loan deals. However, our results remain qualitatively similar to the baseline specification.

We conduct a series of additional robustness tests that we include in the table B1 in the online appendix. First, we use only bank fixed effects, add purpose fixed effects, or cluster the standard errors by year or by loan. Second, we use alternative methods to weight the Lerner index, instead of using equal shares for the members of the syndicate (see also De Haas and Van Horen, 2013). Third, we use a translog specification (instead of the nonparametric specification). The results are equivalent to those reported in our baseline regression.

Overall, our findings in this section confirm our first hypothesis: relatively poor performing firms are matched with banks with relatively high market power. Essentially, we provide the first empirical test of an important element of the theoretical contribution by Petersen and Rajan (1995) and Boot and Thakor (2000) on the way the bank-firm relationships are formed, especially given the role of bank market power. In turn, these results show that the presence of banks with market power can be important in providing credit to relatively poor-performing firms, even in relatively competitive markets like the syndicated loan market.

\subsection{The effect of bank market power on firm performance after the loan origination}

Turning to the examination of $\mathrm{H} 2$, we estimate equation (2) with ROA in the year $t+1$ as the dependent variable and report the results in Table 4 . We estimate all models with the full set of control variables and with bank and firm fixed effects, and we verify that the findings are 
very similar if we exclude the firm and/ or the bank-level controls. To account for the possibility of a mean-reversion problem, we also include firm $\mathrm{ROA}_{t}$ as an as an explanatory variable of $\mathrm{ROA}_{\mathrm{t}+1}$. In most specifications, the coefficient on the lagged dependent variable is positive and statistically significant.

[Insert Table 4 about here]

Further, we examine whether the effect of the Lerner index is non-linear by adding its squared term. This is equivalent to our suggestion in Section 2 that bank market power is beneficial for future firm performance, but too much bank market power will eventually lead to lower performance. Even though the squared term is by itself statistically insignificant in most of the models, the F-test for the joint significance of the Lerner index and its squared term (the p-value is reported in the bottom part of the table), shows that the relation is indeed an inverted U-shaped (bell-shaped). We can in fact calculate the point at which the effect of market power turns negative (turning point) by using the first derivative of the estimated equation with respect to the Lerner index. For instance, in column I this yields a value equal to 0.692 , which is within the range of the Lerner index, but corresponds to only 218 loan facilities ( 0.9 percent of the sample) for which bank market power lowers future firm returns. This small economic effect of the squared term is intuitive given the relative competitiveness of the syndicated loan market. ${ }^{11}$ Even though the impact of the squared term is economically small, we keep it in the subsequent specifications for reasons of completeness and we use specification I of Table 4 as our baseline.

In models II and III of Table 4 we conduct an equivalent analysis with that of models II and III of Table 3, by using data at the loan-deal level and lead-arranger only, respectively. The results remain qualitatively similar to the ones in our benchmark specification. The turning point (where the impact of the Lerner index on $\mathrm{ROA}_{t+1}$ becomes negative) in column

\footnotetext{
${ }^{11}$ We would expect that this effect would be quite larger in local loan markets with only few available lenders.
} 
III is quite lower and there are 290 loan facilities (7.8\% of the lead-arranger sample) for which a higher bank market power actually lowers future firm returns.

The column IV in Table 4 is a quite interesting test for our identification purposes. In this equation, we draw data only for the loan facilities in which the syndicate members (banks and firms) are repeated. This allows for a powerful test of the effect of the Lerner index on ROA because, given the firm and bank fixed effects, only the time variation in the Lerner index (and in the weights used to construct the Lerner index) will play a role in determining future ROA. The results are equivalent to those of the baseline specification I, showing that our findings are robust to endogeneity arising from differences in the structure of the syndicate.

In the rest of the specifications of Table 4, we provide a series of robustness tests in a similar fashion with Table 3. In column $\mathrm{V}$ we exclude the loans granted for LBOs and M\&As, in column VI we exclude term loans, and in column VII we exclude the top three US. The statistical significance of market power is very similar across these three respecifications. The finding that excluding the term loans does not have an impact on our findings shows that the loan type does not play a role in the nexus between market power and future firm performance. The same is prevalent in the rest of the specifications, where the effect of Revolver is a statistically insignificant determinant of firm performance. As expected, excluding the top three banks somewhat lowers the economic significance of market power. $^{12}$

In column VIII of Table 4 we estimate equation (2) using only Commercial Paper Back Up and General Corporate Purpose loans ${ }^{13}$ with results being very similar to the ones in our baseline specification. The idea is that the screening process between borrowers and

\footnotetext{
${ }^{12}$ Related to this finding, a notable result in all the regressions of Table 4 that use $\mathrm{ROA}_{\mathrm{t}+1}$ as dependent variable is that Revolver is statistically insignificant.

${ }^{13}$ These contracts allow firms to borrow up to a predetermined amount of funds at a fixed spread over a safe market benchmark interest rate such as London Interbank Offered Rate (LIBOR). With Commercial Paper Back Up and General Corporate Purpose contract, banks can provide firms with insurance against liquidity shocks.
} 
lenders is less relevant for these loans (Ross, 2010) because they are given to borrowers that have already demonstrated their creditworthiness to the syndicated market. Thus, the fact that results do not change from our baseline model, allows us to attribute most of the effect of market power to the superior monitoring capacity of banks with market power.

As a final, yet quite important sensitivity analysis to deal with the identification problem, by using an instrumental variable (IV) and a two-stage least squares estimator. Specifically, we use as an IV a dummy variable that takes the value one when the bank receives a formal regulatory enforcement action (for violation of laws, rules, and regulations) and zero otherwise. We use only those formal enforcement actions that are related to violations of rules of the internal control and audit systems of banks, as well the management of information (Delis, Staikouras, and Tsoumas, 2015). We expect that this class of enforcement actions is positively correlated with bank market power. The intuition is that banks with high market power will be less transparent with respect to their internal control and audit systems, precisely because they would be incentivized to hide their market power from the regulatory authorities. We do not expect that the regulatory actions of this kind will have a direct effect on firm performance, conditional on the rest of the bank-level control variables and the bank fixed effects.

We report the estimation results in column IX of Table 4. The enforcement actions dummy is indeed a positive and statistically determinant of the Lerner index in the first stage (coefficient estimate equals 0.003 , t-statistic equals 4.72 ). The coefficient estimates on the Lerner index are qualitative similar compared to the baseline specification. Also, the statistical significance and inference on the bell-shaped relation are very similar. The turning point is 0.326 and corresponds to 334 loan facilities (1.1 percent of the sample) for which bank market power is harmful for future firm performance. 
Our data set and framework provides the opportunity to also test the theory of the relation between loan rates and competition in banking (Keeley, 1990; Petersen and Rajan, 1995). As a proxy for loan pricing we use AISD and in line with the most recent literature on this issue (e.g., Martinez-Miera and Repullo, 2010) we consider a non-linear effect of market power by adding the squared term of the Lerner index. Our results (column X of Table 4) indeed indicate a non-linear effect: an increase in bank market power increases AISD up to a level of the Lerner index equal to 0.414 and decreases AISD from that point onward (for approximately $2.5 \%$ of our sample).

Besides the findings reported in Table 4, we conduct a series of other robustness tests and report them in Table B2 in the online Appendix. First, we use three alternative measures of firm performance (panel A), namely Tobin's q, ROI, and Leverage. In line with our expectations and the results on ROA, we find that the Lerner index has a positive impact on Tobin's q and ROI and a negative impact on Leverage. Further, in panel B we experiment with different methods to estimate the Lerner index (columns V-VII) and alternatives methods to weight the Lerner index (columns VIII-IX of online Appendix B2). Again the results are equivalent to those of Table 4.

In sum, our findings in this section suggest that $\mathrm{H} 2$ is confirmed: Bank market power has a positive effect on the performance of the borrowing firms after the origination of the loan for most of the loan facilities in our sample. From this viewpoint our findings confirm the theoretical considerations pointing to the positive real effects of bank market power (Boot and Thakor, 2000; Caminal and Matutes, 1997, 2002). However, we also find limited evidence that for very high levels of market power and for few loan facilities the results reverse. The fact that we analyze the syndicated loan market, which by its very nature is rather competitive, leads us to interpret this finding as evidence in favor of the theory by Boyd and De Nicolo (2005) on the risk-shifting effect. 
[Insert Table 5 about here]

\subsection{The effect of the monitoring effort on firm performance after the loan origination}

In the specifications of Table 5 we dig deeper into the monitoring-effort explanation of our results, based on the theoretical considerations discussed in section 2. Specifically, we introduce a number of interaction terms between the Lerner index and variables that characterize the monitoring incentives of banks. First, we assume that banks with market power will have a superior ability to use soft information during the monitoring process, whereas banks with less market power have to rely more on hard devices, such as written agreements for collateral, covenants, and performance pricing provisions.

To distinguish between soft and hard information we regress the loan amount (weighted by the shares of the banks in the syndicate) on the variables Downgrading, Default, Financial covenants, Collateral, Maturity, Performance pricing, and a set of bank dummies. These explanatory variables encompass the hard information used by banks in the monitoring process of the loan, while the residuals (named soft monitoring) encompass the soft information. Subsequently, we expect that the interplay between the interaction term of these residuals and the Lerner index will be positively associated with future firm performance, if indeed banks with higher market power are better equipped to use soft monitoring to guide firms after the loan origination. Indeed, we find some evidence (reported in column I of Table 5) that as soft monitoring improves, the positive effect of the Lerner index on future firm ROA strengthens.

In the specifications of columns II to VI we include interaction terms between the Lerner index and variables directly used in the literature to proxy the incentives to monitor the loan (e.g., Sufi, 2007). In column II we interact the Lerner index with the number of lenders. The underlying assumption in this specification is that the higher the number of 
lenders in the syndicated loan, the more intense the monitoring process of the loan. The interaction term is positive and statistically significant at the 10 percent level, suggesting that as the number of lenders increases (more intense loan monitoring) the positive effect of the Lerner index reinforces.

In column III we interact the Lerner index with the ratio of the deal amount (weighted by the shares of the banks in the syndicate) to the firm's total assets (Dass and Massa, 2011). We assume that this variable (named loan significance) is also positively correlated with the incentives to monitor the loan because of the large amount of this loan relative to the size of the firm. Similarly to the previous two specifications, we find that as the loan significance increases, the effect of the Lerner index on firm ROA strengthens.

In column $\mathrm{V}$ we interact the Lerner index with the loan amount held by the syndicate members. Allen, Carletti, and Marquez (2011) suggest that "banks grant loans and monitor them, which helps improve firms' performance". Monitoring is costly and one way of providing banks with incentives is through the amount held by each syndicate member. Higher total exposure means that banks will internalize the cost of firms' default. Thus, we assume that the total exposure is positively correlated with the monitoring effort and will determine the probability of success of the investment project (Sufi, 2007). The main effect of the Lerner index comes out positive and statistically significant as before. The interaction term is also positive and statistically significant at the 5 percent level, indicating that the higher is bank exposure, the higher the positive impact of the Lerner index on firm's future performance. In column $\mathrm{V}$ we repeat the same analysis at the lead-arranger level instead of loan-facility level, the results being similar to those of column IV.

In the last column of Table 5 we introduce an interaction term between the Lerner index and performance pricing. Performance pricing is interpreted as the main variable characterizing the monitoring incentives of the banks on paper (hard monitoring). However, 
in this case we do not find a statistically significant coefficient on the interaction term. Thus, it seems that the soft monitoring capacity of banks with market power plays a more important role compared to the monitoring process documented on paper (hard monitoring) in enhancing the future performance of firms. In general, the results from specifications II-VI provide evidence that the higher the monitoring incentives of banks and the higher the capacity of banks to monitor the loan based on soft information, the more potent the effect of market power on future firm ROA.

\section{Conclusions}

Motivated by seminal theoretical contributions, we empirically investigate the correspondence between bank market power and firm performance, both before and after loan origination. In particular we examine 25,236 syndicated loan facilities granted between 2000 and 2010 by 296 banks to 9,029 US non-financial firms. We find that the firms that are relatively poorly-performing match with banks with high market power. And even more importantly, we find a direct and positive effect of bank market power on firm profitability. Both findings are economically relevant and robust to the use of alternative profitability measures, and alterations in samples and model specifications.

Our estimates thus suggest that moderate levels of bank market power not only facilitate access to credit by poorly-performing firms but also boost the performance of those firms that obtain it. In contrast to other markets, policymaking may therefore have to not unilaterally focus on maximizing competition between banks. An interesting extension of our analysis is to examine the relation between bank market power and firm performance based on who initiates the relationship, the bank or the firm. We expect that such an analysis would shed more light on whether the identified relation between bank market power and firm performance is mainly driven by the initiative of relatively worse-performing firms to obtain 
credit or by the incentives of banks with market power. Given data availability issues and the ground we already cover in this paper, we leave this analysis for future research. 


\section{References}

Adams, R.B., Ferreira, D., 2009. Women in the boardroom and their impact on governance and performance. Journal of Financial Economics 94, 291-309.

Allen, F., Carletti, E., Marquez, R., 2011. Credit market competition and capital regulation. Review of Financial Studies 24, 983-1018.

Beck, T., De Jonghe, O., Schepens, G., 2013. Bank competition and stability: Cross-country heterogeneity. Journal of financial Intermediation 22, 218-244.

Besanko, D.A., Kanatas, G., 1993. Credit market equilibrium with bank monitoring and moral hazard. Review of Financial Studies 6, 213-232.

Besanko, D.A., Thakor, A.V., 1992. Banking deregulation: Allocational consequences of relaxing entry barriers. Journal of Banking and Finance 16, pp. 909-32.

Bikker, J., Shaffer, S., Spierdijk, L., 2012. Assessing competition with Panzar-Rosse model: The role of scale, costs, and equilibrium. The Review of Economics and Statistics 94, 1025-1044.

Boone, J., 2008. A new way to measure competition. The Economic Journal 118, 1245-1261.

Boot, A., Thakor A., 2000. Can relationship banking survive competition? Journal of Finance $55,679-713$.

Boyd, J.H., De Nicolo, G., 2005. The theory of bank risk taking and competition revisited. The Journal of Finance 60, 1329-1343.

Cai, J., Saunders, A., Steffen, S., 2012. Syndication, interconnectedness, and systemic risk. Social Science Research Network Working Paper Series.

Carey, M., Nini, G., 2007. Is the corporate loan market globally integrated? A pricing puzzle. The Journal of Finance 62, 2969-3007.

Cetorelli, N., 2004. Real effects of bank competition. Journal of Money, Credit, and Banking $36,543-558$. 
Caminal, R., Matutes, C., 1997. Can competition in the credit market be excessive? Center for Economic Policy Research, Discussion paper 1725.

Caminal, R., Matutes, C., 2002. Market power and banking failures. International Journal of Industrial Organization 20, 1341-1361.

Chan, Y.S., Greenbaum, S., Thakor, A., 1986. Information reusability, competition and bank asset quality. Journal of Banking and Finance 10, 243-253.

Dass, N., Massa, M., 2011. The impact of a strong bank-firm relationship on the borrowing firm. Review of Financial Studies 24, 1204-1260.

De Haas, R., Van Horen, N., 2013. Running for the exit? International bank lending during a financial crisis. Review of Financial Studies 26, 244-285.

Delis, M., 2012. Bank competition, financial reform, and institutions: The importance of being development. Journal of Development Economics 92, 450-465.

Delis, M., Iosifidi, M., Tsionas, E., 2014. On the estimation of marginal cost. Operations Research 62, 543-556.

Delis, M., Kokas., S., Ongena, S., 2015. Foreign ownership and market power in banking: Evidence from a world sample. Journal of Money, Credit and Banking, Forthcoming.

Delis, M.D., Staikouras, P., Tsoumas, C., 2015. Formal enforcement actions and bank behavior. Management Science, forthcoming.

Dennis, S., Mullineaux, D.J., 2000. Syndicated loans. Journal of Financial Intermediation 9, 404-426.

Diamond, D., 1991. Monitoring and reputation: The choice between bank loans and directly placed debt. Journal of Political Economy 99, 689-721.

Fan, J., Zhang, W., 1999. Statistical estimation in varying coefficient models. The Annals of Statistics 27, 1491-1518. 
Gormley, T.A., Matsa, D.A., 2014. Common errors: How to (and not to) control for unobserved heterogeneity. Review of Financial Studies 27, 617-661.

Hoover, D. R., J. A., Rice, C. O., Wu, L., Yang, L.P., 1998. Nonparametric smoothing estimates of time-varying coefficient models with longitudinal data. Biometrica 85, 809-822.

Ivashina, V., Scharfstein, D., 2010. Bank lending during the financial crisis of 2008. Journal of Financial Economics 97, 319-338.

Ivashina, V., Kovner, A., 2011. The private equity advantage: leveraged buyout firms and relationship banking. Review of Financial Studies 24, 2462-2498.

Jiménez, G., Lopez, J.A., Saurina, J., 2013. How does competition affect bank risk-taking? Journal of Financial Stability 9, 185-195.

Jiménez, G., Ongena, S., Peydró, J.L., Saurina, J., 2012. Credit supply and monetary policy: Identifying the bank balance-sheet channel with loan applications. American Economic Review 102, 2301-2326.

Jiménez, G., Ongena, S., Peydró, J.L., Saurina, J., 2014. Hazardous times for monetary policy: What do twenty-three million bank loans say about the effects of monetary policy on credit risk? Econometrica 82, 463-505.

Keeley, M., 1990. Deposit insurance, risk, and market power in banking. The American Economic Review 80, 1183-1200.

Khwaja, A.I., Mian, A., 2008. Tracing the impact of bank liquidity shocks. American Economic Review 98, 1413-1442.

Kim, M., Kristiansen, E.G., Vale, B., 2005. Endogenous product differentiation in credit markets: What do borrowers pay for? Journal of Banking and Finance 29, 681-699.

Lerner, A.P., 1934. The concept of monopoly and the measurement of monopoly power. The Review of Economic Studies 1, 157-175. 
Li, Q., Huang, C.J., Li, D., Fu, T.T., 2002. Semiparametric smooth coefficient models. Journal of Business and Economic Statistics 20, 412-22.

Mamuneas, T., Savvides, A., Stengos, T., 2005. Economic development and the return to human capital: A smooth coefficient semiparametric approach. Journal of Applied Econometrics 21, 111-132.

Martinez-Miera, D., Repullo, R., 2010. Does competition reduce the risk of bank failure?. Review of Financial Studies 23, 3638-3664.

Panzar, J., Rosse, J., 1987. Testing for 'monopoly' equilibrium. Journal of Industrial Economic 35, 443-456.

Petersen, M., Rajan, R., 1995. The effect of credit market competition on lending relationships. Quarterly Journal of Economics 110, 403-444.

Ross, D.G., 2010. The "dominant bank effect:" How high lender reputation affects the information content and terms of bank loans. Review of Financial Studies 23, 27302756.

Schiersch, A., Schmidt-Ehmcke, J., 2010. Empiricism meets theory: Is the Boone-indicator applicable? DIW Berlin, Discussion Paper 1030.

Song, W. L., 2004. Competition and coalition among underwriters: The decision to join a syndicate. The Journal of Finance 59, 2421-2444.

Sufi, A., 2007. Information asymmetry and financing arrangements: Evidence from syndicated loans. Journal of Finance 62, 629-668.

Sufi, A., 2009. Bank lines of credit in corporate finance: An empirical analysis. Review of Financial Studies 22, 1057-1088.

Zhang, W., Lee, S. Y., Song, X., 2002. Local polynomial fitting in semivarying coefficient model. Journal of Multivariate Analysis 82, 166-188. 


\begin{tabular}{|c|c|}
\hline Variable & Definition \\
\hline \multicolumn{2}{|l|}{$\underline{\text { Dependent variables }}$} \\
\hline ROA & The ratio of net income to total assets. \\
\hline Tobin's q & The natural logarithm of the market-to-book value. \\
\hline ROI & The ratio of income before extraordinary items to total assets. \\
\hline Leverage & The ratio of long-term debt to total assets. \\
\hline Lerner index & $\begin{array}{l}L I_{b t}=\frac{P_{b t}-M C_{b t}}{P_{b t}} W_{b t} \text {, where } \mathrm{P} \text { and } \mathrm{MC} \text { are the price of bank output at time } \mathrm{t} \\
\text { and the marginal cost of the production of this output weighted by the shares } \\
\text { of each bank } \mathrm{W} \text { in the syndicated loan (equal shares are imposed where this } \\
\text { information is not available). Marginal cost is estimated using a log-linear } \\
\text { production function and total output is measured by total earning assets. }\end{array}$ \\
\hline $\begin{array}{l}\text { Lerner weighted by } \\
\text { predicted shares }\end{array}$ & $\begin{array}{l}\text { We estimate the shares } W \text { from a model in which the loan amount of } \\
\text { individual lenders is the dependent variable and a number of characteristics of } \\
\text { the syndicate are the explanatory variables. We then use the estimated } \\
\text { coefficients to predict the loan portion for those lenders for whom we do not } \\
\text { know the actual amounts. }\end{array}$ \\
\hline $\begin{array}{l}\text { Lerner weighted by bank } \\
\text { market shares }\end{array}$ & $\begin{array}{l}\text { We calculate the shares } W \text { as the market share that each bank has in the US } \\
\text { market per quarter. }\end{array}$ \\
\hline $\begin{array}{l}\text { Lerner from linear cost } \\
\text { function }\end{array}$ & $\begin{array}{l}\text { Variant of the Lerner index where the marginal cost is estimated using a } \\
\text { linear production function. }\end{array}$ \\
\hline Lerner from total assets & $\begin{array}{l}\text { Variant of the Lerner index where the marginal cost is estimated using total } \\
\text { assets as the bank output. }\end{array}$ \\
\hline Lerner from translog & $\begin{array}{l}\text { Variant of the Lerner index where the marginal cost is estimated with } \\
\text { parametric techniques (OLS) and a translog cost function. }\end{array}$ \\
\hline AISD & $\begin{array}{l}\text { The all-in-spread-drawn (AISD), describes the amount the borrower pays in } \\
\text { basis points over LIBOR for each dollar drawn down. }\end{array}$ \\
\hline
\end{tabular}

\author{
Compustat \\ Id. \\ Id. \\ Id. \\ Own estimations \\ based on data \\ from the Call \\ Reports
}

\section{Id.}

Id.

Id.

Id.

Id.

Dealscan

Own estimations based on data from DealScan DealScan

Id.

Id.

Id.

Id.

Id.

Id.

NGRB

\section{Bank-level explanatory variables}

Non-performing loans

Tier 1 capital

Interest expenses
The ratio of non-performing loans to total loans weighted by the shares of each bank in the syndicated loan.

The ratio of Tier 1 capital to total loans weighted by the shares of each bank in the syndicated loan.

The ratio of interest expenses to total assets weighted by the shares of each bank in the syndicated loan.

\section{Call Reports}

Id.

Id. 


\begin{tabular}{ll}
\hline Bank size & The natural logarithm of total assets weighted by the shares of each bank in Id. \\
the syndicated loan. & The ratio of total deposits to total assets weighted by the shares of each bank Id. \\
in the syndicated loan.
\end{tabular}

\section{Firm-level explanatory variables}

Number of loans

Firm size

Client

Firm efficiency

Firm age

Firm sales

\section{Monitoring variables}

Soft information

Number of lenders

Loan significance

Total exposure

Instrumental Variable

Sanction
The total number of syndicated loans that a firm has received during a year.

The natural logarithm of total assets.

A dummy variable equal to one if the firm has had a previous lending relationship with the lead arranger in the past five years.

The ratio of firm sales to total assets.

Total years since founding.

Natural logarithm of sales over turnover (net).

We regress the loan amount (weighted by the shares of the bank in the syndicate) on the loan-level variables and a set of bank dummies. These explanatory variables encompass the hard information used by banks in the monitoring process of the loan. We then use the residuals to encompass the soft information.

The number of lenders that participate in a syndicated loan.

The loan amount (weighted by the shares of the bank in the syndicate) over the firm's total assets.

The loan amount (in millions) weighted by the shares of the bank in the syndicate.

A dummy variable equal to one when the banks receives a regulatory enforcement action (for violation of laws, rules, and regulations) and zero otherwise.
DealScan

Compustat

DealScan

Compustat

Compustat

Own estimations based on data from DealScan

DealScan

Own estimations based on data from DealScan

Own estimations based on data from DealScan

Hand collected 
Table 2. Summary statistics

The table reports summary statistics for the variables used in the empirical analysis. The variables are defined in Table 1.

\begin{tabular}{|c|c|c|c|c|c|c|}
\hline Variable & Level & Obs. & Mean & Std. Dev. & Min. & Max. \\
\hline$\overline{\mathrm{ROA}}$ & Firm & 27,646 & 0.015 & 0.456 & -49.874 & 1.279 \\
\hline Tobin's q & Firm & 24,552 & 0.500 & 0.390 & -0.883 & 3.012 \\
\hline ROI & Firm & 28,875 & 0.028 & 0.179 & -4.195 & 11.566 \\
\hline Leverage & Firm & 28,865 & 0.300 & 0.218 & 0.000 & 6.879 \\
\hline Lerner index & Bank & 28,786 & 0.037 & 0.051 & -0.172 & 0.881 \\
\hline Lerner weighted by predicted shares & Bank & 28,811 & 0.028 & 0.040 & -0.050 & 0.688 \\
\hline Lerner weighted by bank market shares & Bank & 28,811 & 0.130 & 0.124 & -0.173 & 0.915 \\
\hline Lerner from linear cost function & Bank & 28,786 & 0.037 & 0.051 & -0.166 & 0.879 \\
\hline Lerner from total assets & Bank & 28,789 & 0.042 & 0.057 & -0.126 & 0.889 \\
\hline Lerner from translog & Bank & 28,691 & 0.025 & 0.042 & -0.097 & 0.887 \\
\hline AISD & Loan & 28,875 & 141.206 & 109.555 & 8.500 & $1,300.0$ \\
\hline Loan scale & Loan & 28,705 & 0.329 & 1.582 & 0.000 & 189.433 \\
\hline Downgrading & Loan & 28,875 & 0.274 & 0.446 & 0.000 & 1.000 \\
\hline Default & Loan & 28,875 & 0.024 & 0.154 & 0.000 & 1.000 \\
\hline Financial covenants & Loan & 28,875 & 1.924 & 1.498 & 0.000 & 7.000 \\
\hline Collateral & Loan & 28,875 & 0.377 & 0.485 & 0.000 & 1.000 \\
\hline Maturity & Loan & 28,875 & 3.574 & 0.704 & 0.000 & 5.257 \\
\hline Deal amount & Loan & 28,875 & 6.113 & 1.239 & -0.734 & 10.653 \\
\hline Performance pricing & Loan & 28,875 & 0.660 & 0.474 & 0.000 & 1.000 \\
\hline Non-performing loans & Bank & 28,001 & 0.000 & 0.001 & 0.000 & 0.072 \\
\hline Tier 1 capital & Bank & 28,001 & 0.019 & 0.044 & 0.000 & 2.432 \\
\hline Interest expenses & Bank & 28,850 & 0.002 & 0.003 & 0.000 & 0.046 \\
\hline Bank size & Bank & 28,001 & 2.147 & 2.760 & 0.000 & 20.928 \\
\hline Deposits & Bank & 28,001 & 0.078 & 0.105 & 0.000 & 0.924 \\
\hline Number of loans & Firm & 28,875 & 1.324 & 0.613 & 1.000 & 5.000 \\
\hline Firm size & Firm & 25,101 & 7.935 & 1.750 & -0.254 & 14.458 \\
\hline Client & Firm & 28,875 & 0.572 & 0.495 & 0.000 & 1.000 \\
\hline Firm efficiency & Firm & 25,067 & 0.981 & 0.828 & -0.095 & 11.623 \\
\hline Firm age & Firm & 28,875 & 23.802 & 17.575 & 1.000 & 60.000 \\
\hline Firm sales & Firm & 25,042 & 7.562 & 1.633 & -4.200 & 12.564 \\
\hline Revolver & Loan & 28,875 & 0.809 & 0.393 & 0.000 & 1.000 \\
\hline Soft information & Loan & 28,850 & 1.698 & 149.987 & 0.000 & 6784.103 \\
\hline Number of lenders & Loan & 28,875 & 15.730 & 10.613 & 1.000 & 177.000 \\
\hline Loan significance & Loan & 28,680 & 0.045 & 0.410 & 0.000 & 47.358 \\
\hline Total exposure & Loan & 28,850 & 59.818 & 154.456 & 0.000 & $7,050.916$ \\
\hline Sanction & Bank & 28,875 & 0.006 & 0.077 & 0.000 & 1.000 \\
\hline \multicolumn{7}{|c|}{ Variations for the main variables of interest across loans } \\
\hline \multirow[t]{2}{*}{ ROA } & \multicolumn{4}{|c|}{ Between: } & \multicolumn{2}{|l|}{0.140} \\
\hline & \multicolumn{4}{|c|}{ Within: } & \multicolumn{2}{|l|}{0.454} \\
\hline \multirow[t]{2}{*}{ Lerner index } & \multicolumn{4}{|c|}{ Between: } & \multicolumn{2}{|l|}{0.106} \\
\hline & \multicolumn{4}{|c|}{ Within: } & \multicolumn{2}{|l|}{0.068} \\
\hline
\end{tabular}


Table 3. Bank market power and firm performance before the loan origination

This Table reports coefficients and t-statistics (in parentheses) for equation 1. The dependent variable is the Lerner index. The variables are defined in Table 1. Each observation in the regressions corresponds to a different loan facility. Column I shows the results for our baseline regression. In columns II and III we conduct the analysis at the loan-deal level and only for the lead arrangers, respectively. In column IV we exclude loans granted for Leveraged Buyouts (LBOs) or Mergers and Acquisitions (M\&As). In column V, we restrict our sample only to revolver loans. In column VI, we exclude loans from the top three US banks. All regressions include bank and firm fixed effects and the standard errors are robust with different levels of clustering as shown in the last row of the Table. The *, **, *** marks denote statistical significance at the 10,5 , and $1 \%$ level, respectively.

\begin{tabular}{|c|c|c|c|c|c|c|}
\hline & $\mathrm{I}$ & II & III & IV & $\mathrm{V}$ & VI \\
\hline & Baseline & $\begin{array}{l}\text { Loan-deal } \\
\text { level }\end{array}$ & $\begin{array}{l}\text { Lead } \\
\text { arranger } \\
\text { only }\end{array}$ & $\begin{array}{l}\text { Exclude loans } \\
\text { for LBOs and } \\
\text { M\&As }\end{array}$ & $\begin{array}{l}\text { Revolver } \\
\text { loans only }\end{array}$ & $\begin{array}{l}\text { Exclude loans } \\
\text { from top three } \\
\text { banks }\end{array}$ \\
\hline Firm $\mathrm{ROA}_{\mathrm{t}-1}$ & $\begin{array}{l}-0.009^{* *} \\
(-2.167)\end{array}$ & $\begin{array}{l}-0.013 * * \\
(-2.324)\end{array}$ & $\begin{array}{l}-0.038^{*} \\
(-1.853)\end{array}$ & $\begin{array}{l}-0.009^{* *} \\
(-2.244)\end{array}$ & $\begin{array}{l}-0.010^{* *} \\
(-2.433)\end{array}$ & $\begin{array}{l}-0.014 * * \\
(-2.298)\end{array}$ \\
\hline Loan scale & $\begin{array}{l}-0.000 \\
(-0.259)\end{array}$ & $\begin{array}{l}0.001 \\
(0.429)\end{array}$ & $\begin{array}{l}0.005^{* *} \\
(2.252)\end{array}$ & $\begin{array}{l}0.000 \\
(0.402)\end{array}$ & $\begin{array}{l}-0.000 \\
(-0.027)\end{array}$ & $\begin{array}{l}0.000 \\
(0.431)\end{array}$ \\
\hline Downgrading & $\begin{array}{l}0.000 \\
(1.109)\end{array}$ & $\begin{array}{l}-0.000 \\
(-0.376)\end{array}$ & $\begin{array}{l}0.002 \\
(0.772)\end{array}$ & $\begin{array}{l}0.001^{*} \\
(1.758)\end{array}$ & $\begin{array}{l}0.000 \\
(0.704)\end{array}$ & $\begin{array}{l}-0.001 \\
(-0.928)\end{array}$ \\
\hline Default & $\begin{array}{l}0.002 \\
(1.030)\end{array}$ & $\begin{array}{l}0.005 \\
(1.510)\end{array}$ & $\begin{array}{l}0.003 \\
(0.265)\end{array}$ & $\begin{array}{l}0.002 \\
(0.945)\end{array}$ & $\begin{array}{l}-0.000 \\
(-0.445)\end{array}$ & $\begin{array}{l}0.007^{* *} \\
(2.295)\end{array}$ \\
\hline Financial covenant & $\begin{array}{l}-0.000 \\
(-0.991)\end{array}$ & $\begin{array}{l}-0.001 \\
(-1.558)\end{array}$ & $\begin{array}{l}-0.001 \\
(-0.791)\end{array}$ & $\begin{array}{l}-0.000 \\
(-1.277)\end{array}$ & $\begin{array}{l}0.000 \\
(0.040)\end{array}$ & $\begin{array}{l}-0.000 \\
(-1.379)\end{array}$ \\
\hline Collateral & $\begin{array}{l}-0.001^{*} \\
(-1.955)\end{array}$ & $\begin{array}{l}-0.001 \\
(-0.450)\end{array}$ & $\begin{array}{l}0.001 \\
(0.419)\end{array}$ & $\begin{array}{l}-0.000 \\
(-0.315)\end{array}$ & $\begin{array}{l}-0.001 * * \\
(-2.250)\end{array}$ & $\begin{array}{l}0.001 \\
(0.676)\end{array}$ \\
\hline Maturity & $\begin{array}{l}-0.000 \\
(-0.851)\end{array}$ & $\begin{array}{l}-0.000 \\
(-0.511)\end{array}$ & $\begin{array}{l}0.000 \\
(0.241)\end{array}$ & $\begin{array}{l}-0.000 \\
(-1.010)\end{array}$ & $\begin{array}{l}-0.000 \\
(-0.297)\end{array}$ & $\begin{array}{l}0.000 \\
(0.556)\end{array}$ \\
\hline Deal amount & $\begin{array}{l}-0.002^{* * * *} \\
(-3.981)\end{array}$ & $\begin{array}{l}-0.005^{* * *} \\
(-7.066)\end{array}$ & $\begin{array}{l}-0.008^{* * *} \\
(-4.176)\end{array}$ & $\begin{array}{l}-0.002 * * * \\
(-3.989)\end{array}$ & $\begin{array}{l}-0.002 * * * \\
(-4.496)\end{array}$ & $\begin{array}{l}-0.003 * * * \\
(-5.228)\end{array}$ \\
\hline Performance pricing & $\begin{array}{l}-0.000 \\
(-0.853)\end{array}$ & $\begin{array}{l}-0.000 \\
(-0.530)\end{array}$ & $\begin{array}{l}0.000 \\
(0.002)\end{array}$ & $\begin{array}{l}-0.001 \\
(-1.362)\end{array}$ & $\begin{array}{l}-0.001 \\
(-1.171)\end{array}$ & $\begin{array}{l}-0.001 \\
(-1.169)\end{array}$ \\
\hline Non-performing loans & $\begin{array}{l}0.276 \\
(0.323)\end{array}$ & $\begin{array}{l}0.412 \\
(0.798)\end{array}$ & $\begin{array}{l}1.966^{*} \\
(1.925)\end{array}$ & $\begin{array}{l}0.445 \\
(0.550)\end{array}$ & $\begin{array}{l}0.358 \\
(0.472)\end{array}$ & $\begin{array}{l}0.033 \\
(0.045)\end{array}$ \\
\hline Tier 1 capital & $\begin{array}{l}0.003 \\
(0.131)\end{array}$ & $\begin{array}{l}0.007 \\
(0.456)\end{array}$ & $\begin{array}{l}0.150 \\
(1.425)\end{array}$ & $\begin{array}{l}-0.002 \\
(-0.103)\end{array}$ & $\begin{array}{l}-0.005 \\
(-0.278)\end{array}$ & $\begin{array}{l}0.029 \\
(0.630)\end{array}$ \\
\hline Bank size & $\begin{array}{l}0.017 * * * \\
(5.863)\end{array}$ & $\begin{array}{l}0.018^{* * *} \\
(16.198)\end{array}$ & $\begin{array}{l}0.019 * * * \\
(5.287)\end{array}$ & $\begin{array}{l}0.017 * * * \\
(5.926)\end{array}$ & $\begin{array}{l}0.018^{* * *} \\
(5.665)\end{array}$ & $\begin{array}{l}0.020^{* * *} \\
(15.798)\end{array}$ \\
\hline Deposits & $\begin{array}{l}-0.020 \\
(-0.282)\end{array}$ & $\begin{array}{l}-0.039 \\
(-1.349)\end{array}$ & $\begin{array}{l}-0.111 \\
(-1.187)\end{array}$ & $\begin{array}{l}-0.009 \\
(-0.126)\end{array}$ & $\begin{array}{l}-0.020 \\
(-0.274)\end{array}$ & $\begin{array}{l}-0.077 * * \\
(-2.359)\end{array}$ \\
\hline Number of loans & $\begin{array}{l}0.000 \\
(1.227)\end{array}$ & $\begin{array}{l}-0.000 \\
(-0.194)\end{array}$ & $\begin{array}{l}-0.001 \\
(-0.582)\end{array}$ & $\begin{array}{l}0.000 \\
(0.882)\end{array}$ & $\begin{array}{l}-0.000 \\
(-0.084)\end{array}$ & $\begin{array}{l}0.001 \\
(1.208)\end{array}$ \\
\hline Firm size & $\begin{array}{l}-0.003 * * \\
(-2.153)\end{array}$ & $\begin{array}{l}-0.002 \\
(-0.699)\end{array}$ & $\begin{array}{l}-0.001 \\
(-0.096)\end{array}$ & $\begin{array}{l}-0.004^{* *} \\
(-2.230)\end{array}$ & $\begin{array}{l}-0.001 \\
(-1.354)\end{array}$ & $\begin{array}{l}-0.001 \\
(-0.491)\end{array}$ \\
\hline Client & $\begin{array}{l}-0.001 * * * \\
(-4.408)\end{array}$ & $\begin{array}{l}-0.004 * * * \\
(-5.123)\end{array}$ & $\begin{array}{l}-0.003^{*} \\
(-1.959)\end{array}$ & $\begin{array}{l}-0.001 * * * \\
(-4.464)\end{array}$ & $\begin{array}{l}-0.001 * * * \\
(-3.676)\end{array}$ & $\begin{array}{l}-0.001 * * * \\
(-2.657)\end{array}$ \\
\hline Firm efficiency & $\begin{array}{l}-0.002 \\
(-1.442)\end{array}$ & $\begin{array}{l}-0.003 \\
(-1.397)\end{array}$ & $\begin{array}{l}-0.003 \\
(-0.307)\end{array}$ & $\begin{array}{l}-0.003 \\
(-1.478)\end{array}$ & $\begin{array}{l}-0.001 \\
(-0.821)\end{array}$ & $\begin{array}{l}-0.000 \\
(-0.332)\end{array}$ \\
\hline Firm age & $\begin{array}{l}-0.000 \\
(-0.828)\end{array}$ & $\begin{array}{l}-0.000 \\
(-1.502)\end{array}$ & $\begin{array}{l}-0.001^{* *} \\
(-2.033)\end{array}$ & $\begin{array}{l}-0.000 \\
(-0.680)\end{array}$ & $\begin{array}{l}-0.000 \\
(-1.184)\end{array}$ & $\begin{array}{l}-0.000 \\
(-0.867)\end{array}$ \\
\hline Firm sales & $\begin{array}{l}-0.000 \\
(-0.257)\end{array}$ & $\begin{array}{l}-0.003 \\
(-1.399)\end{array}$ & $\begin{array}{l}0.001 \\
(0.214)\end{array}$ & $\begin{array}{l}0.000 \\
(0.235)\end{array}$ & $\begin{array}{l}-0.001 \\
(-1.176)\end{array}$ & $\begin{array}{l}-0.002 \\
(-1.069)\end{array}$ \\
\hline Revolver & $\begin{array}{l}0.001^{* *} \\
(2.073)\end{array}$ & $\begin{array}{l}0.002 * * * \\
(2.788)\end{array}$ & $\begin{array}{l}0.000 \\
(0.144)\end{array}$ & $\begin{array}{l}0.001^{* *} \\
(2.428)\end{array}$ & & $\begin{array}{l}0.001 * \\
(1.911) \\
\end{array}$ \\
\hline Bank Fixed Effects & Yes & Yes & Yes & Yes & Yes & Yes \\
\hline Firm Fixed Effects & Yes & Yes & Yes & Yes & Yes & Yes \\
\hline Observations & 24,940 & 9,758 & 2,240 & 21,897 & 20,298 & 11,997 \\
\hline Adjusted R-squared & 0.947 & 0.909 & 0.963 & 0.931 & 0.949 & 0.931 \\
\hline Cluster & Bank & Loan & Loan & Bank & Bank & Loan \\
\hline
\end{tabular}


Table 4. The impact of bank's market power on firm performance after the loan origination

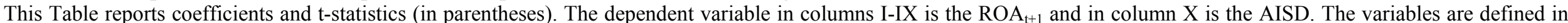

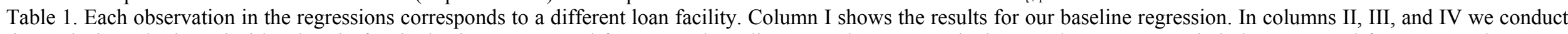

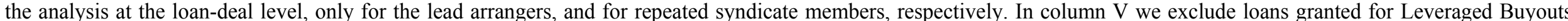

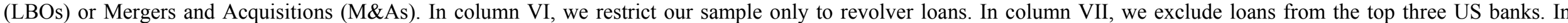

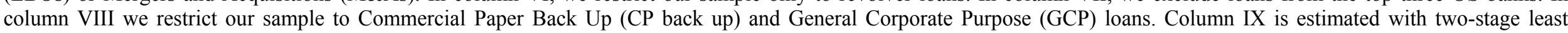

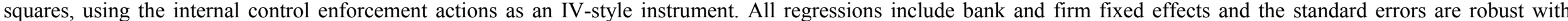

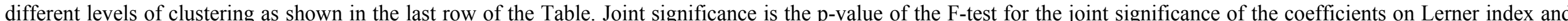

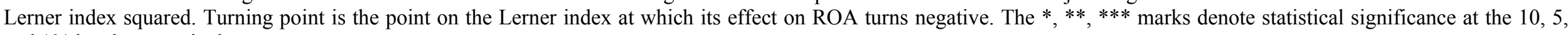
and $1 \%$ level, respectively

\begin{tabular}{|c|c|c|c|c|c|c|c|c|c|c|}
\hline & $\mathrm{I}$ & II & III & $\overline{I I V}$ & $\mathrm{~V}$ & $\overline{\mathrm{VI}}$ & VII & "VIII & IIX & $\bar{X}$ \\
\hline & Baseline & $\begin{array}{l}\text { Loan-deal } \\
\text { level } \\
\text { analysis }\end{array}$ & $\begin{array}{l}\text { Lead } \\
\text { arranger } \\
\text { only }\end{array}$ & $\begin{array}{l}\text { Repeated } \\
\text { syndicate } \\
\text { members }\end{array}$ & $\begin{array}{l}\text { Exclude } \\
\text { loans for } \\
\text { LBO and } \\
\text { M\&A's }\end{array}$ & $\begin{array}{l}\text { Revolver } \\
\text { loan only }\end{array}$ & $\begin{array}{l}\text { Exclude } \\
\text { loans } \\
\text { from top } \\
\text { three } \\
\text { banks } \\
\end{array}$ & $\begin{array}{l}\text { Only loans } \\
\text { for CP } \\
\text { back up } \\
\text { and GCP }\end{array}$ & $2 \mathrm{SLS}$ & AISD \\
\hline $\mathrm{ROA}_{\mathrm{t}}$ & $\begin{array}{l}0.225 * * * \\
(4.765)\end{array}$ & $\begin{array}{l}0.202 * * * \\
(4.962)\end{array}$ & $\begin{array}{l}0.299 * * * \\
(4.025)\end{array}$ & $\begin{array}{l}0.121 * * \\
(2.366)\end{array}$ & $\begin{array}{l}0.232 * * * \\
(3.565)\end{array}$ & $\begin{array}{l}0.215^{* * *} \\
(4.483)\end{array}$ & $\begin{array}{l}0.184 * * * \\
(3.441)\end{array}$ & $\begin{array}{l}0.220 \\
(1.376)\end{array}$ & $\begin{array}{l}0.315^{* * *} \\
(5.446)\end{array}$ & $\begin{array}{l}-93.066 * * * \\
(-4.477)\end{array}$ \\
\hline Lerner index & $\begin{array}{l}0.345 * * * \\
(3.507)\end{array}$ & $\begin{array}{l}0.360 * * * \\
(3.712)\end{array}$ & $\begin{array}{l}0.472 * * \\
(2.237)\end{array}$ & $\begin{array}{l}0.363^{* *} \\
(2.352)\end{array}$ & $\begin{array}{l}0.383 * * * \\
(3.522)\end{array}$ & $\begin{array}{l}0.326 * * * \\
(3.686)\end{array}$ & $\begin{array}{l}0.242 * * * \\
(2.741)\end{array}$ & $\begin{array}{l}0.507 * * \\
(2.255)\end{array}$ & $\begin{array}{l}0.436^{* * *} \\
(3.481)\end{array}$ & $\begin{array}{l}300.594 * * * \\
(3.641)\end{array}$ \\
\hline Lerner index squared & $\begin{array}{l}-0.249 \\
(-1.234)\end{array}$ & $\begin{array}{l}-0.246 \\
(-1.338)\end{array}$ & $\begin{array}{l}-0.745^{* * *} \\
(-2.650)\end{array}$ & $\begin{array}{l}-0.480 \\
(-1.311)\end{array}$ & $\begin{array}{l}-0.313 \\
(-1.339)\end{array}$ & $\begin{array}{l}-0.138 \\
(-0.857)\end{array}$ & $\begin{array}{l}-0.047 \\
(-0.285)\end{array}$ & $\begin{array}{l}-0.960^{*} \\
(-1.858)\end{array}$ & $\begin{array}{l}-0.667 * * * \\
(-3.555)\end{array}$ & $\begin{array}{l}-362.981^{*} \\
(-1.735)\end{array}$ \\
\hline Downgrading & $\begin{array}{l}-0.020 * * * \\
(-4.991)\end{array}$ & $\begin{array}{l}-0.018 * * * \\
(-5.491)\end{array}$ & $\begin{array}{l}-0.016^{* *} \\
(-2.498)\end{array}$ & $\begin{array}{l}-0.021 * * * \\
(-3.397)\end{array}$ & $\begin{array}{l}-0.021 * * * \\
(-5.009)\end{array}$ & $\begin{array}{l}-0.019 * * * \\
(-4.764)\end{array}$ & $\begin{array}{l}-0.034 * * * \\
(-5.652)\end{array}$ & $\begin{array}{l}-0.018 * * * \\
(-3.035)\end{array}$ & $\begin{array}{l}-0.024 * * * \\
(-5.828)\end{array}$ & $\begin{array}{l}-12.230 * * * \\
(-3.202)\end{array}$ \\
\hline Default & $\begin{array}{l}-0.052 * * * \\
(-3.047)\end{array}$ & $\begin{array}{l}-0.058 * * \\
(-2.474)\end{array}$ & $\begin{array}{l}-0.078 \\
(-1.569)\end{array}$ & $\begin{array}{l}-0.056 \\
(-0.982)\end{array}$ & $\begin{array}{l}-0.055^{* * *} \\
(-2.658)\end{array}$ & $\begin{array}{l}-0.065 * * * \\
(-2.927)\end{array}$ & $\begin{array}{l}-0.071 * * * \\
(-2.725)\end{array}$ & $\begin{array}{l}-0.014 \\
(-0.611)\end{array}$ & $\begin{array}{l}-0.104 * * * \\
(-2.836)\end{array}$ & $\begin{array}{l}10.450 \\
(0.756)\end{array}$ \\
\hline Financial covenant & $\begin{array}{l}-0.002 \\
(-1.089)\end{array}$ & $\begin{array}{l}-0.003 \\
(-1.359)\end{array}$ & $\begin{array}{l}-0.001 \\
(-0.274)\end{array}$ & $\begin{array}{l}-0.002 \\
(-0.692)\end{array}$ & $\begin{array}{l}-0.003 \\
(-1.332)\end{array}$ & $\begin{array}{l}-0.000 \\
(-0.166)\end{array}$ & $\begin{array}{l}-0.002 \\
(-0.967)\end{array}$ & $\begin{array}{l}-0.004 \\
(-0.677)\end{array}$ & $\begin{array}{l}-0.003 \\
(-1.488)\end{array}$ & $\begin{array}{l}5.828 * * * \\
(4.228)\end{array}$ \\
\hline Collateral & $\begin{array}{l}-0.004 \\
(-0.539)\end{array}$ & $\begin{array}{l}-0.000 \\
(-0.040)\end{array}$ & $\begin{array}{l}-0.005 \\
(-0.649)\end{array}$ & $\begin{array}{l}-0.007 \\
(-0.649)\end{array}$ & $\begin{array}{l}-0.001 \\
(-0.094)\end{array}$ & $\begin{array}{l}-0.005 \\
(-0.741)\end{array}$ & $\begin{array}{l}0.003 \\
(0.568)\end{array}$ & $\begin{array}{l}0.019 \\
(1.322)\end{array}$ & $\begin{array}{l}-0.020 * * * \\
(-4.177)\end{array}$ & $\begin{array}{l}38.542 * * * \\
(7.296)\end{array}$ \\
\hline Maturity & $\begin{array}{l}0.006^{* * * *} \\
(2.901)\end{array}$ & $\begin{array}{l}0.005 * * * \\
(3.347)\end{array}$ & $\begin{array}{l}0.005^{*} \\
(1.746)\end{array}$ & $\begin{array}{l}0.004^{* *} \\
(2.301)\end{array}$ & $\begin{array}{l}0.007 * * * \\
(3.198)\end{array}$ & $\begin{array}{l}0.007 * * * \\
(2.837)\end{array}$ & $\begin{array}{l}0.001 \\
(0.389)\end{array}$ & $\begin{array}{l}0.006^{*} \\
(1.795)\end{array}$ & $\begin{array}{l}0.007 * * * \\
(2.837)\end{array}$ & $\begin{array}{l}-4.890 * * * \\
(-3.151)\end{array}$ \\
\hline Deal amount & $\begin{array}{l}-0.008 * * \\
(-2.095)\end{array}$ & $\begin{array}{l}-0.009 * * * \\
(-3.751)\end{array}$ & $\begin{array}{l}-0.009 * * \\
(-2.495)\end{array}$ & $\begin{array}{l}-0.010^{* *} \\
(-2.161)\end{array}$ & $\begin{array}{l}-0.006 \\
(-1.602)\end{array}$ & $\begin{array}{l}-0.005 \\
(-1.379)\end{array}$ & $\begin{array}{l}-0.010^{* *} \\
(-2.383)\end{array}$ & $\begin{array}{l}-0.002 \\
(-0.342)\end{array}$ & $\begin{array}{l}-0.002 \\
(-1.032)\end{array}$ & $\begin{array}{l}-0.607 \\
(-0.299)\end{array}$ \\
\hline Performance pricing & $\begin{array}{l}0.007 \\
(1.542)\end{array}$ & $\begin{array}{l}0.007^{*} \\
(1.940)\end{array}$ & $\begin{array}{l}0.006 \\
(1.302)\end{array}$ & $\begin{array}{l}0.014^{* *} \\
(2.410)\end{array}$ & $\begin{array}{l}0.006 \\
(1.088)\end{array}$ & $\begin{array}{l}0.003 \\
(0.450)\end{array}$ & $\begin{array}{l}0.008^{*} \\
(1.922)\end{array}$ & $\begin{array}{l}0.004 \\
(0.436)\end{array}$ & $\begin{array}{l}0.005 \\
(1.041)\end{array}$ & $\begin{array}{l}-18.792 * * * \\
(-5.701)\end{array}$ \\
\hline Non-performing loans & $\begin{array}{l}-0.712 \\
(-1.153)\end{array}$ & $\begin{array}{l}-0.958 \\
(-1.167)\end{array}$ & $\begin{array}{l}-0.775 \\
(-0.622)\end{array}$ & $\begin{array}{l}-0.223 \\
(-0.152)\end{array}$ & $\begin{array}{l}-1.011^{*} \\
(-1.664)\end{array}$ & $\begin{array}{l}-0.766 \\
(-1.276)\end{array}$ & $\begin{array}{l}-1.142 \\
(-1.492)\end{array}$ & $\begin{array}{l}-0.500 \\
(-0.534)\end{array}$ & $\begin{array}{l}-1.404 \\
(-1.382)\end{array}$ & $\begin{array}{l}4.702 * * * \\
(3.480)\end{array}$ \\
\hline Tier 1 capital & $\begin{array}{l}0.018 \\
(1.307)\end{array}$ & $\begin{array}{l}0.015 \\
(0.955)\end{array}$ & $\begin{array}{l}0.256^{*} \\
(1.731)\end{array}$ & $\begin{array}{l}-0.001 \\
(-0.042)\end{array}$ & $\begin{array}{l}0.024 * \\
(1.745)\end{array}$ & $\begin{array}{l}0.021 \\
(1.504)\end{array}$ & $\begin{array}{l}0.063 * * \\
(2.547)\end{array}$ & $\begin{array}{l}0.007 \\
(0.310)\end{array}$ & $\begin{array}{l}0.044 * * \\
(2.122)\end{array}$ & $\begin{array}{l}-47.940 * * \\
(-2.406)\end{array}$ \\
\hline Interest expenses & $-2.622 * * *$ & $-1.165^{* *}$ & -1.971 & -1.414 & $-3.148 * * *$ & $-2.517 * * *$ & -0.995 & $-4.531 * * *$ & $-2.354 * * *$ & $-4.515 * * *$ \\
\hline
\end{tabular}




\begin{tabular}{|c|c|c|c|c|c|c|c|c|c|c|}
\hline & $(-3.136)$ & $(-2.101)$ & $(-1.283)$ & $(-1.602)$ & $(-3.440)$ & $(-3.002)$ & $(-1.074)$ & $(-3.379)$ & $(-2.733)$ & $(-6.640)$ \\
\hline \multirow[t]{2}{*}{ Bank size } & $-0.006 * *$ & $-0.006 * *$ & -0.008 & $-0.006^{*}$ & $-0.006 * *$ & $-0.005 * *$ & $-0.009 * * *$ & 0.000 & -0.002 & $4.523 * *$ \\
\hline & $(-2.525)$ & $(-2.003)$ & $(-1.145)$ & $(-1.833)$ & $(-2.239)$ & $(-2.325)$ & $(-3.847)$ & $(0.082)$ & $(-0.595)$ & $(2.048)$ \\
\hline \multirow[t]{2}{*}{ Deposits } & 0.088 & 0.039 & 0.106 & $0.149 *$ & 0.096 & 0.044 & $0.122 * * *$ & -0.024 & -0.076 & $-110.695 * * *$ \\
\hline & (1.609) & $(0.700)$ & $(0.758)$ & $(1.750)$ & $(1.555)$ & $(0.932)$ & $(2.591)$ & $(-0.350)$ & $(-1.559)$ & $(-2.781)$ \\
\hline \multirow[t]{2}{*}{ Number of loans } & $-0.007 * *$ & $-0.010 * * *$ & $-0.021 * * *$ & $-0.007 *$ & $-0.009 * *$ & $-0.009 * *$ & $-0.011 * *$ & $-0.011 * *$ & -0.005 & $10.534 * * *$ \\
\hline & $(-2.168)$ & $(-3.615)$ & $(-2.973)$ & $(-1.881)$ & $(-2.344)$ & $(-2.315)$ & $(-2.038)$ & $(-1.997)$ & $(-1.539)$ & $(3.405)$ \\
\hline \multirow[t]{2}{*}{ Firm size } & $-0.024^{*}$ & $-0.020 *$ & -0.024 & -0.022 & -0.020 & -0.020 & $-0.030 * * *$ & -0.028 & $-0.011 * * *$ & 10.455 \\
\hline & $(-1.922)$ & $(-1.823)$ & $(-1.519)$ & $(-1.124)$ & $(-1.324)$ & $(-1.631)$ & $(-2.585)$ & $(-0.918)$ & $(-3.276)$ & $(1.426)$ \\
\hline \multirow{2}{*}{ Client } & 0.001 & -0.001 & 0.007 & 0.005 & 0.000 & 0.002 & -0.002 & -0.002 & -0.000 & $-4.386^{*}$ \\
\hline & $(0.447)$ & $(-0.297)$ & (1.399) & $(1.327)$ & $(0.214)$ & $(1.056)$ & $(-0.556)$ & $(-0.806)$ & $(-0.148)$ & $(-1.954)$ \\
\hline \multirow[t]{2}{*}{ Firm efficiency } & 0.008 & $0.011 * *$ & 0.018 & $0.020^{*}$ & $0.015^{* *}$ & $0.010^{*}$ & 0.006 & 0.015 & -0.002 & -0.128 \\
\hline & $(1.453)$ & $(2.075)$ & $(1.084)$ & $(1.879)$ & $(2.110)$ & $(1.801)$ & (1.499) & $(1.171)$ & $(-0.755)$ & $(-0.026)$ \\
\hline \multirow{2}{*}{ Firm age } & 0.000 & 0.001 & 0.000 & 0.001 & 0.000 & -0.000 & -0.002 & 0.000 & 0.000 & $1.722 * * *$ \\
\hline & $(0.315)$ & $(0.849)$ & $(0.395)$ & $(0.403)$ & $(0.342)$ & $(-0.440)$ & $(-1.547)$ & $(0.064)$ & $(0.087)$ & $(2.700)$ \\
\hline \multirow[t]{2}{*}{ Firm sales } & 0.001 & 0.000 & -0.001 & -0.002 & -0.004 & 0.002 & $0.024^{*}$ & 0.001 & $0.012 * * *$ & $-34.083 * * *$ \\
\hline & $(0.087)$ & $(0.009)$ & $(-0.070)$ & $(-0.151)$ & $(-0.320)$ & $(0.152)$ & $(1.728)$ & $(0.041)$ & $(3.668)$ & $(-3.718)$ \\
\hline \multirow[t]{2}{*}{ Revolver } & 0.002 & 0.001 & 0.001 & 0.002 & 0.002 & & -0.000 & $0.007^{*}$ & 0.003 & $-23.272 * * *$ \\
\hline & $(0.892)$ & $(0.612)$ & $(0.368)$ & $(0.637)$ & $(0.737)$ & & $(-0.281)$ & $(1.763)$ & $(0.907)$ & $(-11.826)$ \\
\hline Bank Fixed Effects & Yes & Yes & Yes & Yes & Yes & Yes & Yes & Yes & No & Yes \\
\hline Firm Fixed Effects & Yes & Yes & Yes & Yes & Yes & Yes & Yes & Yes & No & Yes \\
\hline IV & No & No & No & No & No & No & No & No & Yes & No \\
\hline Observations & 23,993 & 9,334 & 2,836 & 4,005 & 21,743 & 19,605 & 12,104 & 11,809 & 23,993 & 24,895 \\
\hline Hansen (P-value) & & & & & & & & & 0.113 & \\
\hline F(P-value) & & & & & & & & & 0.000 & \\
\hline Adjusted R-squared & 0.810 & 0.781 & 0.966 & 0.668 & 0.818 & 0.817 & 0.841 & 0.650 & & 0.781 \\
\hline Joint significance & 0.000 & 0.000 & 0.026 & 0.005 & 0.000 & 0.000 & 0.004 & 0.078 & 0.001 & 0.000 \\
\hline Turning point & 0.692 & 0.731 & 0.316 & 0.378 & 0.611 & 1.181 & 3.025 & 0.264 & 0.326 & 0.414 \\
\hline Cluster & Firm & Loan & Loan & Loan & Firm & Firm & Firm & Firm & Firm & Firm \\
\hline
\end{tabular}


Table 5. The impact of bank's market power on firm corporate performance after the loan origination: Tracing the effect of the monitoring effort

This Table reports coefficients and t-statistics (in parentheses). The dependent variable is the ROA. All specifications include the bank, loan and firm-level controls included in Table 4, except from column II, which does not include the loan-level controls. The variables are defined in Table 1. Each observation in the regressions corresponds to a different loan facility. All regressions include bank and firm fixed effects and the standard errors are clustered by firm. Hansen is the p-value of the Hansen test of overidentifying restrictions. The *, **, *** marks denote statistical significance at the 10,5 , and $1 \%$ level, respectively.

\begin{tabular}{|c|c|c|c|c|c|c|}
\hline & $\overline{\mathrm{II}}$ & $\overline{\mathrm{III}}$ & $\overline{\text { III }}$ & $\overline{\mathrm{IV}}$ & $\overline{\mathrm{V}}$ & VI \\
\hline Dependent variable & ROA & ROA & ROA & ROA & ROA & ROA \\
\hline Firm $\mathrm{ROA}_{t}$ & $\begin{array}{l}0.232 * * * \\
(4.869)\end{array}$ & $\begin{array}{l}0.225^{* * *} \\
(4.753)\end{array}$ & $\begin{array}{l}0.226 * * * \\
(4.767)\end{array}$ & $\begin{array}{l}0.227 * * * \\
(4.812)\end{array}$ & $0.303 * * *$ & $0.224 * * *$ \\
\hline Lerner index & $\begin{array}{l}0.395 * * * \\
(3.881)\end{array}$ & $\begin{array}{l}0.443 * * * \\
(3.736)\end{array}$ & $\begin{array}{l}0.360 * * * \\
(3.375)\end{array}$ & $\begin{array}{l}0.352 * * * \\
(3.426)\end{array}$ & $\begin{array}{l}0.454^{* *} \\
(2.023)\end{array}$ & $\begin{array}{l}0.350^{* * *} \\
(3.316)\end{array}$ \\
\hline Lerner index squared & $\begin{array}{l}-0.382^{*} \\
(-1.700)\end{array}$ & $\begin{array}{l}-0.725 \\
(-0.654)\end{array}$ & $\begin{array}{l}-0.286 \\
(-1.152)\end{array}$ & $\begin{array}{l}-0.239 \\
(-1.055)\end{array}$ & $\begin{array}{l}-0.633 * * \\
(-2.104)\end{array}$ & $\begin{array}{l}-0.331^{*} \\
(-1.723)\end{array}$ \\
\hline Soft information & $\begin{array}{l}-0.000 * * * \\
(-3.410)\end{array}$ & & & & & \\
\hline Lerner index $*$ Soft information & $\begin{array}{l}0.001 * \\
(1.771)\end{array}$ & & & & & \\
\hline Lerner index squared $*$ Soft information & $\begin{array}{l}-0.002 \\
(-1.637)\end{array}$ & & & & & \\
\hline Number of lenders & & $\begin{array}{l}0.000 \\
(0.572)\end{array}$ & & & & \\
\hline Lerner index $*$ Number of lenders & & $\begin{array}{l}0.014^{*} \\
(1.658)\end{array}$ & & & & \\
\hline Lerner index squared $*$ Number of lenders & & $\begin{array}{l}-0.050 \\
(-0.578)\end{array}$ & & & & \\
\hline Loan significance & & & $\begin{array}{l}-0.110^{* *} \\
(-2.391)\end{array}$ & & & \\
\hline Lerner index $*$ Loan significance & & & $\begin{array}{l}0.840 * * \\
(2.246)\end{array}$ & & & \\
\hline Lerner index squared $*$ Loan significance & & & $\begin{array}{l}-1.230^{*} \\
(-1.761)\end{array}$ & & & \\
\hline Total exposure & & & & $\begin{array}{l}-0.000 * * * \\
(-2.805)\end{array}$ & $\begin{array}{l}-0.000 * * * \\
(-3.049)\end{array}$ & \\
\hline Lerner index $*$ Total exposure & & & & $\begin{array}{l}0.001 * * \\
(2.002)\end{array}$ & $\begin{array}{l}0.000^{* *} \\
(2.467)\end{array}$ & \\
\hline Lerner index squared $*$ Total exposure & & & & $\begin{array}{l}-0.002^{*} \\
(-1.886)\end{array}$ & $\begin{array}{l}-0.001^{*} \\
(-1.884)\end{array}$ & \\
\hline Performance pricing & & & & & & $\begin{array}{l}0.007 * \\
(1.767)\end{array}$ \\
\hline Lerner index * Performance pricing & & & & & & $\begin{array}{l}0.051 \\
(0.394)\end{array}$ \\
\hline $\begin{array}{l}\text { Lerner index squared * Performance } \\
\text { pricing }\end{array}$ & & & & & & $\begin{array}{l}-0.304 \\
(-0.900)\end{array}$ \\
\hline Bank Fixed Effects & Yes & Yes & Yes & Yes & Yes & Yes \\
\hline Firm Fixed Effects & Yes & Yes & Yes & Yes & Yes & Yes \\
\hline Lead-lender level & No & No & No & No & Yes & No \\
\hline Observations & 23,394 & 23,394 & 23,394 & 23,394 & 2,163 & 23,394 \\
\hline Adjusted R-squared & 0.801 & 0.803 & 0.804 & 0.803 & 0.970 & 0.803 \\
\hline Bank control characteristics & Yes & Yes & Yes & Yes & Yes & Yes \\
\hline Firm control characteristics & Yes & Yes & Yes & Yes & Yes & Yes \\
\hline Loan control characteristics & No & Yes & Yes & Yes & Yes & Yes \\
\hline
\end{tabular}




\section{Appendix A. Estimation of marginal cost}

We estimate marginal cost using both semi-parametric and parametric estimation methods. For the semi-parametric method, which is the one favored here, we use the following loglinear cost function:

$$
\ln C_{i t}=a_{1}+a_{2}\left(z_{i t}\right) \ln Q_{i t}+a_{3} \ln w_{i t}^{l}+a_{4} \ln w_{i t}^{k}+a_{5} \ln w_{i t}^{d}+e_{i t}
$$

In (A.1) $C$ is the total cost of the bank $i$ at time $t$, measured by the deflated total interest expenses and total noninterest expenses; $Q$ is the total output of each bank, measured by the deflated total earning assets (or simply total assets in robustness tests); $w^{l}$ is the price of labor, measured by the ratio of personnel expenses to total assets; $w^{k}$ is the price of physical capital, measured by the ratio of overheads minus personnel expenses to fixed assets; and $w^{d}$ is the price of intermediation funds, measured by the ratio of total interest expenses to total customer deposits. In alternative specifications, we also include the price of financial capital, as measured by the ratio of equity capital to total assets, as well as measures of bank risk (ratio of non-performing loans or loan-loss provisions to total loans), the results being unaffected. We collect data for these variables from the Call Reports (annual end-year reports).

Equation (A.1) has parametric parts (those related to the input prices) and a nonparametric part (that related to bank output). The variable $z$, which is the so-called smoothing parameter, is crucial for the identification of the model and must be a variable that is highly correlated with $a_{2}$ and considerably varies by bank-year. Delis, Kokas, and Ongena (2015) propose using $z=\ln w_{i t}^{l}+\ln w_{i t}^{k}$, which is intuitive given the high potential correlation of input prices with the output elasticity of costs. We use the same approach and we also verify that using each input price separately yields similar results. Further, we impose the linear homogeneity restriction in input prices by normalizing total cost and the input prices by the 
price of deposits before taking logs. From (A.1) we can obtain the marginal cost at the bankyear level as $\frac{\partial C_{i t}}{\partial Q}=a_{2}\left(\frac{C_{i t}}{Q_{i t}}\right)$ to calculate the Lerner index.

The actual estimation methodology of the semi-parametric model follows the paradigm of Fan and Zhang (1999) and Mamuneas, Savvides, and Stengos (2006). Specifically, and by dropping the $t$ subscript for simplicity, we can write (A.1) in econometric form as follows:

$$
Y_{i}=\mathrm{E}\left(Y_{i} \mid W_{i}\right)+e_{i}=X_{i} \beta_{1}+V_{i} \beta_{2}\left(Z_{i}\right)+e_{i}
$$

In this equation, $\beta_{2}$ is a function of one or more variables with dimension $k$ added to the vector $Z$. The linear part in (A.2) is in line with the idea of the semiparametric model as opposed to a nonparametric model (e.g., Zhang, Lee, and Song, 2002). The coefficients of the linear part are estimated in the first step as averages of the polynomial fitting by using an initial bandwidth chosen by cross-validation (Hoover, Rice, Wu, and Yang, 1998). We then average these estimates $\beta_{1 i}$ and $\beta_{2 i}$ to receive $\beta_{1}$ and $\beta_{2}$ in (A.2).

In the second step we use the average estimates and (A.2) to redefine the dependent variable as follows:

$$
Y_{i}^{*} \equiv Y_{i}-X_{i} \hat{\beta}_{i}=V_{i} \beta_{2}(z)+e_{i}^{*}
$$

where the asterisks denote the redefined dependent variable and error term. $\beta_{2}(z)$ is a vector of smooth but unknown functions of $z_{i}$, estimated using a local least squares of the form

$$
\hat{\beta}_{2}(z)=\left[\left(n \lambda^{k}\right)^{-1} \sum_{j=1}^{n} V_{j}^{2} K\left(\frac{z_{j}-z}{\lambda}\right)\right]^{-1}\left[\left(n \lambda^{k}\right)^{-1} \sum_{j=1}^{n} V_{j} Y_{j}^{*} K\left(\frac{z_{j}-z}{\lambda}\right)\right]=\left[B_{n}(z)\right]^{-1} C_{n}(z),
$$

where $\left.B_{n}(z)=\left(n \lambda^{k}\right)^{-1} \sum_{j=1}^{n} V_{j}^{2} K\left(\frac{z_{j}-z}{\lambda}\right), C_{n}(z)=n \lambda^{k}\right)^{-1} \sum_{j=1}^{n} V_{j} Y_{j}^{*} K\left(\frac{z_{j}-z}{\lambda}\right)$. 
Equation (A.4) represents a local constant estimator, where $K(z, \lambda)$ is a kernel function, $\lambda$ is the smoothing parameter (chosen by generalized cross validation) for sample size $n$, and $k$ is the dimension of $z_{i}$.

If we assume that $z$ is a scalar and $K$ is a uniform kernel, then (A.4) can be written as follows:

$$
\hat{\beta}_{2}(z)=\left[\sum_{\left|z_{j}-z\right| \leq \lambda} V_{j}^{2}\right]^{-1}\left[\sum_{\left|z_{j}-z\right| \leq \lambda} V_{j} Y_{j}^{*}\right] .
$$

In (A.5), $\hat{\beta}_{2}(z)$ is a least squares estimator obtained by regressing $Y_{j}^{*}$ on $V_{j}$, using the observations of $\left(V_{j}, Y_{j}^{*}\right)$ for which the corresponding $z_{j}$ is close to $z$, that is, $\left|z_{j}-z\right| \leq \lambda$. Therefore, to estimate $\hat{\beta}_{2}(z)$, we only use observations within this "sliding window." Note that no assumptions are made about this estimator globally, but locally-within the sliding window-we assume that $\hat{\beta}_{2}(z)$ can be well-approximated. Also, because $\beta_{2}(z)$ is a smooth function of $z,\left|\beta_{2}\left(z_{j}\right)-\beta_{2}(z)\right|$ is small when $\left|z_{j}-z\right|$ is small. The condition that $n \lambda$ is large ensures that we have sufficient observations within the interval $\left|z_{j}-z\right| \leq \lambda$ when $\beta_{2}\left(z_{j}\right)$ is close to $\beta_{2}(z)$. Therefore, under the conditions $\lambda \rightarrow 0$ and $n \lambda^{k} \rightarrow \infty$ (for $k \geq 1$ ), the local least squares regression of $Y_{j}^{*}$ on $V_{j}$ provides a consistent estimate of $\beta_{2}(z)$ (for a proof, see Li, Huang, Li, and Fu, 2002). Therefore, the estimation method is usually referred to as a local regression.

The main merit of this approach is that it is quite more flexible than the usual parametric functional forms (e.g., the translog) and this can lead to substantial improvement in the precision of the estimates. However, we also use a translog specification and the same outputs and input prices and our end results of the paper (those relating to the two hypotheses 
of our paper) remain very similar. We also repeat the analysis using a fully parametric model (i.e., $a_{3}$ to $a_{5}$ are also functions of $\mathrm{z}$ ), with our end results again being similar.

Table A1. Average estimates of market power

This table reports average estimates of market power by year. Averages are obtained from the bank-year level estimates of market power using the Lerner index, as this is defined in equation (3). Higher values reflect higher market power (lower competition).

\begin{tabular}{|c|c|c|c|c|c|c|c|}
\hline \multirow[b]{3}{*}{ Year } & \multirow[b]{3}{*}{$\begin{array}{l}\text { Lerner } \\
\text { index }\end{array}$} & \multirow[b]{3}{*}{$\begin{array}{l}\text { Lerner } \\
\text { index } \\
\text { weighted } \\
\text { by shares }\end{array}$} & \multicolumn{5}{|c|}{ Distribution by bank size } \\
\hline & & & $10^{\text {th }}$ & $25^{\text {th }}$ & $50^{\text {th }}$ & $75^{\text {th }}$ & $90^{\text {th }}$ \\
\hline & & & $\begin{array}{l}\text { Lerner } \\
\text { index } \\
\text { weighted } \\
\text { by shares }\end{array}$ & $\begin{array}{l}\text { Lerner } \\
\text { index } \\
\text { weighted } \\
\text { by shares }\end{array}$ & $\begin{array}{l}\text { Lerner } \\
\text { index } \\
\text { weighted } \\
\text { by shares }\end{array}$ & $\begin{array}{l}\text { Lerner } \\
\text { index } \\
\text { weighted } \\
\text { by shares }\end{array}$ & $\begin{array}{l}\text { Lerner } \\
\text { index } \\
\text { weighted } \\
\text { by shares }\end{array}$ \\
\hline 2000 & 0.240 & 0.037 & 0.005 & 0.009 & 0.014 & 0.019 & 0.024 \\
\hline 2001 & 0.267 & 0.039 & 0.006 & 0.010 & 0.015 & 0.022 & 0.028 \\
\hline 2002 & 0.357 & 0.050 & 0.007 & 0.013 & 0.021 & 0.032 & 0.038 \\
\hline 2003 & 0.364 & 0.054 & 0.008 & 0.013 & 0.021 & 0.031 & 0.040 \\
\hline 2004 & 0.376 & 0.056 & 0.007 & 0.012 & 0.021 & 0.031 & 0.042 \\
\hline 2005 & 0.332 & 0.052 & 0.007 & 0.012 & 0.018 & 0.028 & 0.038 \\
\hline 2006 & 0.277 & 0.047 & 0.006 & 0.009 & 0.016 & 0.026 & 0.036 \\
\hline 2007 & 0.251 & 0.044 & 0.005 & 0.008 & 0.014 & 0.024 & 0.033 \\
\hline 2008 & 0.262 & 0.049 & 0.006 & 0.010 & 0.016 & 0.024 & 0.035 \\
\hline 2009 & 0.348 & 0.065 & 0.006 & 0.011 & 0.020 & 0.030 & 0.043 \\
\hline 2010 & 0.354 & 0.064 & 0.007 & 0.011 & 0.018 & 0.031 & 0.042 \\
\hline
\end{tabular}


Table B1. Bank market power and firm performance before the loan origination: Sensitivity analysis

This Table reports coefficients and t-statistics (in parentheses). The dependent variable is the Lerner index. The variables are defined in table 1. Each observation in the regressions corresponds to a different loan facility. All regressions include bank and firm fixed effects and the standard errors are robust with different levels of clustering as shown in the last row of the Table. The *, $* *, * * *$ marks denote statistical significance at the 10,5 , and $1 \%$ level, respectively.

\begin{tabular}{|c|c|c|c|c|c|c|c|}
\hline & $\overline{\mathrm{I}}$ & II & III & IV & $\mathrm{V}$ & VI & VII \\
\hline & Bank FE & Purpose FE & Cluster by year & Cluster by loan & $\begin{array}{l}\text { Lerner } \\
\text { weighted } \\
\text { by } \\
\text { predicted } \\
\text { shares }\end{array}$ & $\begin{array}{l}\text { Lerner } \\
\text { weighted } \\
\text { by bank } \\
\text { market } \\
\text { shares }\end{array}$ & $\begin{array}{l}\text { Lerner } \\
\text { from } \\
\text { translog }\end{array}$ \\
\hline Firm $\mathrm{ROA}_{\mathrm{t}-1}$ & $\begin{array}{l}-0.003 * * \\
(-2.317)\end{array}$ & $\begin{array}{l}-0.009 * * \\
(-2.275)\end{array}$ & $\begin{array}{l}-0.009 * * \\
(-3.119)\end{array}$ & $\begin{array}{l}-0.009 * * * \\
(-2.756)\end{array}$ & $\begin{array}{l}-0.007 * * \\
(-2.324)\end{array}$ & $\begin{array}{l}-0.035 * * \\
(-2.495)\end{array}$ & $\begin{array}{l}-0.009^{*} \\
(-1.795)\end{array}$ \\
\hline Loan scale & $\begin{array}{l}-0.000 \\
(-0.051)\end{array}$ & $\begin{array}{l}-0.000 \\
(-0.289)\end{array}$ & $\begin{array}{l}-0.000 \\
(-0.510)\end{array}$ & $\begin{array}{l}-0.000 \\
(-0.315)\end{array}$ & $\begin{array}{l}-0.000 \\
(-0.119)\end{array}$ & $\begin{array}{l}-0.003 \\
(-1.161)\end{array}$ & $\begin{array}{l}-0.000 \\
(-0.245)\end{array}$ \\
\hline Downgrading & $\begin{array}{l}0.000 * \\
(1.782)\end{array}$ & $\begin{array}{l}0.000 \\
(1.097)\end{array}$ & $\begin{array}{l}0.000 * \\
(1.954)\end{array}$ & $\begin{array}{l}0.000 \\
(1.163)\end{array}$ & $\begin{array}{l}0.000 \\
(0.977)\end{array}$ & $\begin{array}{l}0.002 * * \\
(2.010)\end{array}$ & $\begin{array}{l}0.001 \\
(1.502)\end{array}$ \\
\hline Default & $\begin{array}{l}0.000 \\
(0.296)\end{array}$ & $\begin{array}{l}0.002 \\
(1.034)\end{array}$ & $\begin{array}{l}0.002 \\
(1.571)\end{array}$ & $\begin{array}{l}0.002 \\
(1.151)\end{array}$ & $\begin{array}{l}0.002 \\
(1.065)\end{array}$ & $\begin{array}{l}-0.003 \\
(-0.447)\end{array}$ & $\begin{array}{l}0.002 \\
(0.872)\end{array}$ \\
\hline Financial covenant & $\begin{array}{l}0.000 \\
(1.033)\end{array}$ & $\begin{array}{l}-0.000 \\
(-0.916)\end{array}$ & $\begin{array}{l}-0.000 \\
(-1.040)\end{array}$ & $\begin{array}{l}-0.000 \\
(-1.542)\end{array}$ & $\begin{array}{l}0.000 \\
(0.733)\end{array}$ & $\begin{array}{l}0.002 * * \\
(2.444)\end{array}$ & $\begin{array}{l}-0.000 \\
(-1.249)\end{array}$ \\
\hline Collateral & $\begin{array}{l}-0.001 \\
(-1.303)\end{array}$ & $\begin{array}{l}-0.000 \\
(-1.567)\end{array}$ & $\begin{array}{l}-0.001 \\
(-1.067)\end{array}$ & $\begin{array}{l}-0.001 \\
(-1.080)\end{array}$ & $\begin{array}{l}-0.001 * * \\
(-2.004)\end{array}$ & $\begin{array}{l}-0.006 * * * \\
(-3.750)\end{array}$ & $\begin{array}{l}-0.001 * * * \\
(-2.706)\end{array}$ \\
\hline Maturity & $\begin{array}{l}-0.001 * * * \\
(-2.606)\end{array}$ & $\begin{array}{l}-0.000 \\
(-0.742)\end{array}$ & $\begin{array}{l}-0.000 \\
(-0.569)\end{array}$ & $\begin{array}{l}-0.000 \\
(-1.155)\end{array}$ & $\begin{array}{l}-0.000 * * \\
(-2.436)\end{array}$ & $\begin{array}{l}-0.002 * * \\
(-2.465)\end{array}$ & $\begin{array}{l}-0.000 \\
(-0.981)\end{array}$ \\
\hline Deal amount & $\begin{array}{l}-0.001 * * \\
(-2.559)\end{array}$ & $\begin{array}{l}-0.002 * * * \\
(-4.082)\end{array}$ & $\begin{array}{l}-0.002 * * * \\
(-4.818)\end{array}$ & $\begin{array}{l}-0.002 * * * \\
(-6.390)\end{array}$ & $\begin{array}{l}-0.001 * * * \\
(-2.673)\end{array}$ & $\begin{array}{l}-0.007 * * * \\
(-3.466)\end{array}$ & $\begin{array}{l}-0.003 * * * \\
(-4.117)\end{array}$ \\
\hline Performance pricing & $\begin{array}{l}-0.001^{*} \\
(-1.832)\end{array}$ & $\begin{array}{l}-0.000 \\
(-0.744)\end{array}$ & $\begin{array}{l}-0.000 \\
(-0.985)\end{array}$ & $\begin{array}{l}-0.000 \\
(-0.843)\end{array}$ & $\begin{array}{l}0.000 \\
(0.436)\end{array}$ & $\begin{array}{l}-0.002 \\
(-1.094)\end{array}$ & $\begin{array}{l}-0.001 \\
(-1.628)\end{array}$ \\
\hline Non-performing loans & $\begin{array}{l}-0.641 \\
(-0.363)\end{array}$ & $\begin{array}{l}0.276 \\
(0.324)\end{array}$ & $\begin{array}{l}0.276 \\
(0.380)\end{array}$ & $\begin{array}{l}0.276 \\
(0.592)\end{array}$ & $\begin{array}{l}1.695 \\
(1.352)\end{array}$ & $\begin{array}{l}-0.260 \\
(-0.242)\end{array}$ & $\begin{array}{l}0.121 \\
(0.114)\end{array}$ \\
\hline Tier 1 capital & $\begin{array}{l}0.038 \\
(0.756)\end{array}$ & $\begin{array}{l}0.003 \\
(0.129)\end{array}$ & $\begin{array}{l}0.003 \\
(0.186)\end{array}$ & $\begin{array}{l}0.003 \\
(0.215)\end{array}$ & $\begin{array}{l}-0.021 \\
(-0.869)\end{array}$ & $\begin{array}{l}0.017 \\
(0.706)\end{array}$ & $\begin{array}{l}0.015 \\
(0.517)\end{array}$ \\
\hline Bank size & $\begin{array}{l}0.013 * * * \\
(3.215)\end{array}$ & $\begin{array}{l}0.017 * * * \\
(5.906)\end{array}$ & $\begin{array}{l}0.017 * * * \\
(7.793)\end{array}$ & $\begin{array}{l}0.017 * * * \\
(14.874)\end{array}$ & $\begin{array}{l}0.016 * * * \\
(4.434)\end{array}$ & $\begin{array}{l}0.017 * * * \\
(5.875)\end{array}$ & $\begin{array}{l}0.010 * * \\
(2.081)\end{array}$ \\
\hline Deposits & $\begin{array}{l}0.105 \\
(1.113)\end{array}$ & $\begin{array}{l}-0.019 \\
(-0.276)\end{array}$ & $\begin{array}{l}-0.020 \\
(-0.521)\end{array}$ & $\begin{array}{l}-0.020 \\
(-0.642)\end{array}$ & $\begin{array}{l}0.005 \\
(0.060)\end{array}$ & $\begin{array}{l}0.007 \\
(0.094)\end{array}$ & $\begin{array}{l}0.027 \\
(0.243)\end{array}$ \\
\hline Number of loans & $\begin{array}{l}0.000 \\
(0.837)\end{array}$ & $\begin{array}{l}0.000 \\
(1.424)\end{array}$ & $\begin{array}{l}0.000 \\
(0.779)\end{array}$ & $\begin{array}{l}0.000 \\
(1.071)\end{array}$ & $\begin{array}{l}0.000 \\
(0.968)\end{array}$ & $\begin{array}{l}0.002 \\
(1.445)\end{array}$ & $\begin{array}{l}0.000 \\
(0.859)\end{array}$ \\
\hline Firm size & $\begin{array}{l}0.000 \\
(0.126)\end{array}$ & $\begin{array}{l}-0.003 * * \\
(-2.245)\end{array}$ & $\begin{array}{l}-0.003 * * \\
(-2.636)\end{array}$ & $\begin{array}{l}-0.003 * * * \\
(-2.744)\end{array}$ & $\begin{array}{l}-0.002^{*} \\
(-1.840)\end{array}$ & $\begin{array}{l}-0.008^{*} \\
(-1.847)\end{array}$ & $\begin{array}{l}-0.004 * * * \\
(-2.659)\end{array}$ \\
\hline Client & $\begin{array}{l}-0.001 * * * \\
(-4.089)\end{array}$ & $\begin{array}{l}-0.001 * * * \\
(-4.467)\end{array}$ & $\begin{array}{l}-0.001 * * * \\
(-4.537)\end{array}$ & $\begin{array}{l}-0.001 * * * \\
(-4.745)\end{array}$ & $\begin{array}{l}-0.001 * * * \\
(-3.313)\end{array}$ & $\begin{array}{l}-0.005 * * * \\
(-4.496)\end{array}$ & $\begin{array}{l}-0.001 * * * \\
(-4.987)\end{array}$ \\
\hline Firm efficiency & $\begin{array}{l}-0.000 \\
(-0.412)\end{array}$ & $\begin{array}{l}-0.002 \\
(-1.361)\end{array}$ & $\begin{array}{l}-0.002 * \\
(-1.990)\end{array}$ & $\begin{array}{l}-0.002 \\
(-1.616)\end{array}$ & $\begin{array}{l}-0.001 \\
(-1.321)\end{array}$ & $\begin{array}{l}-0.003 \\
(-0.826)\end{array}$ & $\begin{array}{l}-0.002 \\
(-1.567)\end{array}$ \\
\hline Firm age & $\begin{array}{l}0.000 \\
(1.482)\end{array}$ & $\begin{array}{l}-0.000 \\
(-1.114)\end{array}$ & $\begin{array}{l}-0.000 \\
(-0.424)\end{array}$ & $\begin{array}{l}-0.000 \\
(-1.070)\end{array}$ & $\begin{array}{l}-0.000 * * \\
(-2.315)\end{array}$ & $\begin{array}{l}-0.001 * * * \\
(-2.637)\end{array}$ & $\begin{array}{l}-0.000 \\
(-1.588)\end{array}$ \\
\hline Firm sales & $\begin{array}{l}-0.000 \\
(-0.200)\end{array}$ & $\begin{array}{l}-0.000 \\
(-0.237)\end{array}$ & $\begin{array}{l}-0.000 \\
(-0.488)\end{array}$ & $\begin{array}{l}-0.000 \\
(-0.279)\end{array}$ & $\begin{array}{l}0.000 \\
(0.229)\end{array}$ & $\begin{array}{l}-0.002 \\
(-0.440)\end{array}$ & $\begin{array}{l}0.000 \\
(0.010)\end{array}$ \\
\hline Revolver & $\begin{array}{l}-0.000 \\
(-0.503)\end{array}$ & $\begin{array}{l}0.000 \\
(1.384)\end{array}$ & $\begin{array}{l}0.001 \\
(1.586)\end{array}$ & $\begin{array}{l}0.001 * * \\
(2.293)\end{array}$ & $\begin{array}{l}0.000^{*} \\
(1.870)\end{array}$ & $\begin{array}{l}0.001 \\
(1.228)\end{array}$ & $\begin{array}{l}0.001 * * \\
(2.454)\end{array}$ \\
\hline Bank Fixed Effects & Yes & Yes & Yes & Yes & Yes & Yes & Yes \\
\hline Firm Fixed Effects & No & Yes & Yes & Yes & Yes & Yes & Yes \\
\hline Observations & 24,940 & 24,940 & 24,940 & 24,326 & 24,326 & 24,272 & 23,963 \\
\hline Adjusted R-squared & 0.861 & 0.948 & 0.787 & 0.947 & 0.918 & 0.898 & 0.839 \\
\hline Cluster & Bank & Bank & Year & Loan & Bank & Bank & Bank \\
\hline
\end{tabular}


Table B2. The impact of bank's market power on corporate performance after the loan origination: Sensitivity analysis

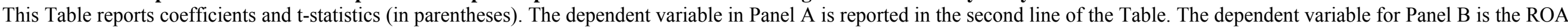

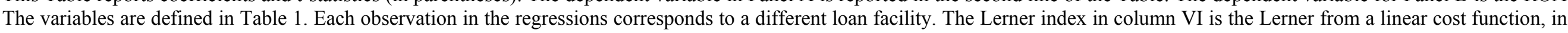

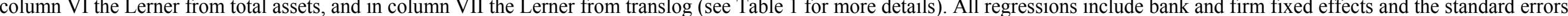

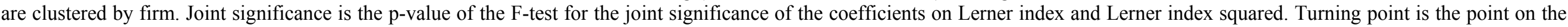
Lerner index at which its effect on ROA turns negative. The *,**,*** marks denote statistical significance at the 10,5 , and $1 \%$ level, respectively.

\begin{tabular}{|c|c|c|c|c|c|c|c|c|c|}
\hline & \multicolumn{3}{|c|}{ Panel A } & \multicolumn{6}{|c|}{ Panel B } \\
\hline & 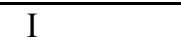 & II & III & $\overline{\mathrm{V}}$ & 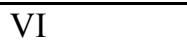 & 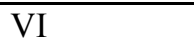 & VII & VIII & IX \\
\hline & Tobin's q & ROI & Leverage & $\begin{array}{l}\text { Linear } \\
\text { analysis }\end{array}$ & $\begin{array}{l}\text { Lerner from } \\
\text { linear cost } \\
\text { function }\end{array}$ & $\begin{array}{l}\text { Lerner from } \\
\text { total assets }\end{array}$ & $\begin{array}{l}\text { Lerner from } \\
\text { translog }\end{array}$ & $\begin{array}{l}\text { Lerner } \\
\text { weighted by } \\
\text { predicted } \\
\text { shares }\end{array}$ & $\begin{array}{l}\text { Lerner } \\
\text { weighted by } \\
\text { bank } \\
\text { market } \\
\text { shares }\end{array}$ \\
\hline Dependent variable $_{t}$ & $\begin{array}{l}0.250 * * * \\
(2.756)\end{array}$ & $\begin{array}{l}0.194 * * * \\
(4.466)\end{array}$ & $\begin{array}{l}-0.145^{* * *} \\
(-3.216)\end{array}$ & $\begin{array}{l}0.225 * * * \\
(4.764)\end{array}$ & $\begin{array}{l}0.225 * * * \\
(4.766)\end{array}$ & $\begin{array}{l}0.225 * * * \\
(4.762)\end{array}$ & $\begin{array}{l}0.225 * * * \\
(4.764)\end{array}$ & $\begin{array}{l}0.227 * * * \\
(4.813)\end{array}$ & $\begin{array}{l}0.226 * * * \\
(4.775)\end{array}$ \\
\hline Lerner index squared & $\begin{array}{l}-1.488^{* * *} \\
(-3.206)\end{array}$ & $\begin{array}{l}-0.084 \\
(-0.481)\end{array}$ & $\begin{array}{l}0.610^{* * * *} \\
(2.844)\end{array}$ & & $\begin{array}{l}-0.221 \\
(-1.108)\end{array}$ & $\begin{array}{l}-0.169 \\
(-0.991)\end{array}$ & $\begin{array}{l}-0.215 \\
(-0.881)\end{array}$ & $\begin{array}{l}-0.440^{* * *} \\
(-2.646)\end{array}$ & $\begin{array}{l}-0.152 * * \\
(-2.063)\end{array}$ \\
\hline Downgrading & $\begin{array}{l}-0.039 * * * \\
(-3.920)\end{array}$ & $\begin{array}{l}-0.019 * * * \\
(-5.000)\end{array}$ & $\begin{array}{l}0.011 * * \\
(2.387)\end{array}$ & $\begin{array}{l}-0.020 * * * \\
(-4.989)\end{array}$ & $\begin{array}{l}-0.020 * * * \\
(-4.992)\end{array}$ & $\begin{array}{l}-0.020 * * * \\
(-4.984)\end{array}$ & $\begin{array}{l}-0.020 * * * \\
(-4.992)\end{array}$ & $\begin{array}{l}-0.020 * * * \\
(-4.961)\end{array}$ & $\begin{array}{l}-0.020 * * * \\
(-4.952)\end{array}$ \\
\hline Default & $\begin{array}{l}0.054^{*} \\
(1.815)\end{array}$ & $\begin{array}{l}-0.055^{* * * *} \\
(-3.089)\end{array}$ & $\begin{array}{l}0.006 \\
(0.237)\end{array}$ & $\begin{array}{l}-0.052 * * * \\
(-3.040)\end{array}$ & $\begin{array}{l}-0.052 * * * \\
(-3.039)\end{array}$ & $\begin{array}{l}-0.052 * * * \\
(-3.032)\end{array}$ & $\begin{array}{l}-0.052 * * * \\
(-3.026)\end{array}$ & $\begin{array}{l}-0.055^{* * *} \\
(-3.242)\end{array}$ & $\begin{array}{l}-0.054 * * * \\
(-3.226)\end{array}$ \\
\hline Financial covenant & $\begin{array}{l}0.011 * * * \\
(3.008)\end{array}$ & $\begin{array}{l}-0.001 \\
(-0.611)\end{array}$ & $\begin{array}{l}-0.006^{*} \\
(-1.804)\end{array}$ & $\begin{array}{l}-0.002 \\
(-1.092)\end{array}$ & $\begin{array}{l}-0.002 \\
(-1.094)\end{array}$ & $\begin{array}{l}-0.002 \\
(-1.110)\end{array}$ & $\begin{array}{l}-0.002 \\
(-1.114)\end{array}$ & $\begin{array}{l}-0.003 \\
(-1.134)\end{array}$ & $\begin{array}{l}-0.002 \\
(-1.127)\end{array}$ \\
\hline Maturity & $\begin{array}{l}0.028 * * * \\
(6.640)\end{array}$ & $\begin{array}{l}0.005 * * \\
(2.552)\end{array}$ & $\begin{array}{l}-0.008^{* * *} \\
(-4.099)\end{array}$ & $\begin{array}{l}0.006 * * * \\
(2.874)\end{array}$ & $\begin{array}{l}0.006 * * * \\
(2.892)\end{array}$ & $\begin{array}{l}0.006 * * * \\
(2.895)\end{array}$ & $\begin{array}{l}0.006 * * * \\
(2.903)\end{array}$ & $\begin{array}{l}0.006 * * * \\
(2.967)\end{array}$ & $\begin{array}{l}0.006 * * * \\
(2.988)\end{array}$ \\
\hline Deal amount & $\begin{array}{l}-0.020^{* * * *} \\
(-3.858)\end{array}$ & $\begin{array}{l}-0.006^{*} \\
(-1.790)\end{array}$ & $\begin{array}{l}0.024 * * * \\
(5.721)\end{array}$ & $\begin{array}{l}-0.008 * * \\
(-2.154)\end{array}$ & $\begin{array}{l}-0.008 * * \\
(-2.116)\end{array}$ & $\begin{array}{l}-0.008 * * \\
(-2.138)\end{array}$ & $\begin{array}{l}-0.008 * * \\
(-2.091)\end{array}$ & $\begin{array}{l}-0.009 * * \\
(-2.448)\end{array}$ & $\begin{array}{l}-0.007 * * \\
(-2.119)\end{array}$ \\
\hline Performance pricing & $\begin{array}{l}-0.017 * * \\
(-2.210)\end{array}$ & $\begin{array}{l}0.005 \\
(1.466)\end{array}$ & $\begin{array}{l}-0.000 \\
(-0.024)\end{array}$ & $\begin{array}{l}0.007 \\
(1.520)\end{array}$ & $\begin{array}{l}0.007 \\
(1.539)\end{array}$ & $\begin{array}{l}0.007 \\
(1.544)\end{array}$ & $\begin{array}{l}0.007 \\
(1.550)\end{array}$ & $\begin{array}{l}0.007 \\
(1.477)\end{array}$ & $\begin{array}{l}0.008 \\
(1.622)\end{array}$ \\
\hline Non-performing loans & $\begin{array}{l}-8.273 * * * \\
(-3.119)\end{array}$ & $\begin{array}{l}-0.463 \\
(-0.696)\end{array}$ & $\begin{array}{l}2.156^{*} \\
(1.898)\end{array}$ & $\begin{array}{l}-0.650 \\
(-1.037)\end{array}$ & $\begin{array}{l}-0.753 \\
(-1.225)\end{array}$ & $\begin{array}{l}-0.587 \\
(-0.942)\end{array}$ & $\begin{array}{l}-0.732 \\
(-1.182)\end{array}$ & $\begin{array}{l}0.260 \\
(0.337)\end{array}$ & $\begin{array}{l}0.031 \\
(0.135)\end{array}$ \\
\hline Tier 1 capital & $\begin{array}{l}0.181 * * * \\
(3.694)\end{array}$ & $\begin{array}{l}0.015 \\
(1.123)\end{array}$ & $\begin{array}{l}-0.025 \\
(-1.074)\end{array}$ & $\begin{array}{l}0.015 \\
(1.124)\end{array}$ & $\begin{array}{l}0.018 \\
(1.375)\end{array}$ & $\begin{array}{l}0.012 \\
(0.915)\end{array}$ & $\begin{array}{l}0.017 \\
(1.302)\end{array}$ & $\begin{array}{l}0.004 \\
(0.265)\end{array}$ & $\begin{array}{l}-0.000 \\
(-0.076)\end{array}$ \\
\hline Interest expenses & $\begin{array}{l}-13.989 * * * \\
(-5.607)\end{array}$ & $\begin{array}{l}-1.634 * * \\
(-2.212)\end{array}$ & $\begin{array}{l}1.438 \\
(1.445)\end{array}$ & $\begin{array}{l}-2.568 * * * \\
(-3.106)\end{array}$ & $\begin{array}{l}-2.777 * * * \\
(-3.330)\end{array}$ & $\begin{array}{l}-2.930^{* * *} \\
(-3.403)\end{array}$ & $\begin{array}{l}-2.988 * * * \\
(-3.609)\end{array}$ & $\begin{array}{l}-2.206^{* * *} \\
(-2.937)\end{array}$ & $\begin{array}{l}-0.687 * * * \\
(-2.835)\end{array}$ \\
\hline Bank size & $\begin{array}{l}-0.011^{*} \\
(-1.828)\end{array}$ & $\begin{array}{l}-0.005 * * * \\
(-2.837)\end{array}$ & $\begin{array}{l}0.004 \\
(1.342)\end{array}$ & $\begin{array}{l}-0.005 * * \\
(-2.360)\end{array}$ & $\begin{array}{l}-0.006 * * \\
(-2.399)\end{array}$ & $\begin{array}{l}-0.006^{* *} \\
(-2.289)\end{array}$ & $\begin{array}{l}-0.003 \\
(-1.390)\end{array}$ & $\begin{array}{l}-0.003 * \\
(-1.649)\end{array}$ & $\begin{array}{l}-0.002 * * \\
(-2.402)\end{array}$ \\
\hline
\end{tabular}




\begin{tabular}{|c|c|c|c|c|c|c|c|c|c|}
\hline Deposits & $\begin{array}{l}0.105 \\
(0.915)\end{array}$ & $\begin{array}{l}0.053 \\
(1.424)\end{array}$ & $\begin{array}{l}-0.025 \\
(-0.424)\end{array}$ & $\begin{array}{l}0.088 \\
(1.604)\end{array}$ & $\begin{array}{l}0.095^{*} \\
(1.712)\end{array}$ & $\begin{array}{l}0.092^{*} \\
(1.665)\end{array}$ & $\begin{array}{l}0.074 \\
(1.378)\end{array}$ & $\begin{array}{l}-0.008 \\
(-0.183)\end{array}$ & $\begin{array}{l}0.020 \\
(1.234)\end{array}$ \\
\hline Number of loans & $\begin{array}{l}-0.007 \\
(-0.795)\end{array}$ & $\begin{array}{l}-0.006^{*} \\
(-1.827)\end{array}$ & $\begin{array}{l}0.015 * * * \\
(3.517)\end{array}$ & $\begin{array}{l}-0.007 * * \\
(-2.163)\end{array}$ & $\begin{array}{l}-0.007 * * \\
(-2.165)\end{array}$ & $\begin{array}{l}-0.007 * * \\
(-2.167)\end{array}$ & $\begin{array}{l}-0.007^{* *} \\
(-2.148)\end{array}$ & $\begin{array}{l}-0.007 * * \\
(-2.131)\end{array}$ & $\begin{array}{l}-0.007 * * \\
(-2.174)\end{array}$ \\
\hline Firm size & $\begin{array}{l}-0.087 * * * \\
(-4.535)\end{array}$ & $\begin{array}{l}-0.026 * * * \\
(-2.846)\end{array}$ & $\begin{array}{l}-0.006 \\
(-0.590)\end{array}$ & $\begin{array}{l}-0.024^{*} \\
(-1.927)\end{array}$ & $\begin{array}{l}-0.024^{*} \\
(-1.924)\end{array}$ & $\begin{array}{l}-0.024^{*} \\
(-1.935)\end{array}$ & $\begin{array}{l}-0.024^{*} \\
(-1.911)\end{array}$ & $\begin{array}{l}-0.025^{*} \\
(-1.953)\end{array}$ & $\begin{array}{l}-0.025^{* *} \\
(-1.984)\end{array}$ \\
\hline Client & $\begin{array}{l}0.004 \\
(0.600)\end{array}$ & $\begin{array}{l}-0.001 \\
(-0.538)\end{array}$ & $\begin{array}{l}0.001 \\
(0.133)\end{array}$ & $\begin{array}{l}0.001 \\
(0.417)\end{array}$ & $\begin{array}{l}0.001 \\
(0.436)\end{array}$ & $\begin{array}{l}0.001 \\
(0.417)\end{array}$ & $\begin{array}{l}0.001 \\
(0.424)\end{array}$ & $\begin{array}{l}0.001 \\
(0.370)\end{array}$ & $\begin{array}{l}0.001 \\
(0.488)\end{array}$ \\
\hline Firm efficiency & $\begin{array}{l}0.009 \\
(0.714)\end{array}$ & $\begin{array}{l}0.006 \\
(1.437)\end{array}$ & $\begin{array}{l}-0.008 \\
(-1.175)\end{array}$ & $\begin{array}{l}0.008 \\
(1.447)\end{array}$ & $\begin{array}{l}0.008 \\
(1.449)\end{array}$ & $\begin{array}{l}0.008 \\
(1.441)\end{array}$ & $\begin{array}{l}0.008 \\
(1.482)\end{array}$ & $\begin{array}{l}0.007 \\
(1.349)\end{array}$ & $\begin{array}{l}0.008 \\
(1.425)\end{array}$ \\
\hline Firm age & $\begin{array}{l}0.001 \\
(0.322)\end{array}$ & $\begin{array}{l}-0.001 \\
(-0.903)\end{array}$ & $\begin{array}{l}0.000 \\
(0.049)\end{array}$ & $\begin{array}{l}0.000 \\
(0.300)\end{array}$ & $\begin{array}{l}0.000 \\
(0.317)\end{array}$ & $\begin{array}{l}0.000 \\
(0.306)\end{array}$ & $\begin{array}{l}0.000 \\
(0.328)\end{array}$ & $\begin{array}{l}0.000 \\
(0.390)\end{array}$ & $\begin{array}{l}0.000 \\
(0.418)\end{array}$ \\
\hline Firm sales & $\begin{array}{l}-0.002 \\
(-0.116)\end{array}$ & $\begin{array}{l}0.009 \\
(0.993)\end{array}$ & $\begin{array}{l}-0.005 \\
(-0.416)\end{array}$ & $\begin{array}{l}0.001 \\
(0.072)\end{array}$ & $\begin{array}{l}0.001 \\
(0.077)\end{array}$ & $\begin{array}{l}0.001 \\
(0.080)\end{array}$ & $\begin{array}{l}0.001 \\
(0.080)\end{array}$ & $\begin{array}{l}0.001 \\
(0.058)\end{array}$ & $\begin{array}{l}0.001 \\
(0.130)\end{array}$ \\
\hline Revolver & $\begin{array}{l}0.007^{*} \\
(1.818)\end{array}$ & $\begin{array}{l}0.002 \\
(1.028)\end{array}$ & $\begin{array}{l}-0.008 * * * \\
(-3.571)\end{array}$ & $\begin{array}{l}0.002 \\
(0.888)\end{array}$ & $\begin{array}{l}0.002 \\
(0.895)\end{array}$ & $\begin{array}{l}0.002 \\
(0.895)\end{array}$ & $\begin{array}{l}0.002 \\
(0.903)\end{array}$ & $\begin{array}{l}0.002 \\
(0.960)\end{array}$ & $\begin{array}{l}0.002 \\
(1.006)\end{array}$ \\
\hline Bank and Fixed Effects & Yes & Yes & Yes & Yes & Yes & Yes & Yes & Yes & Yes \\
\hline Observations & 20,618 & 23,989 & 23,982 & 23,993 & 23,993 & 23,996 & 23,963 & 24,016 & 24,016 \\
\hline Adjusted R-squared & 0.873 & 0.801 & 0.873 & 0.809 & 0.809 & 0.809 & 0.808 & 0.809 & 0.810 \\
\hline Turning point & 0.430 & 1.404 & 0.398 & & 0.717 & 0.804 & 0.560 & 0.410 & 0.565 \\
\hline
\end{tabular}

